\title{
Recent Advances in Mupirocin Delivery Strategies for the Treatment of Bacterial Skin and Soft Tissue Infection
}

\author{
Aishwarya Gangwar ${ }^{1}$, Parveen Kumar ${ }^{2}$, Ranjit Singh ${ }^{3}$ and Preeti Kush ${ }^{3, *(D)}$ \\ 1 Department of Pharmaceutics, Chandigarh College of Pharmacy, Mohali 140307, Punjab, India; \\ aishwaryagangwar@gmail.com \\ 2 Exigo Recycling Pvt. Ltd., Noida 201309, Uttar Pradesh, India; parveenkaushik7@gmail.com \\ 3 School of Pharmacy, Adarsh Vijendra Institute of Pharmaceutical Sciences, Shobhit University Gangoh, \\ Saharanpur 247341, Uttar Pradesh, India; ranjitsps@gmail.com \\ * Correspondence: preetikush85@gmail.com
}

Citation: Gangwar, A.; Kumar, P.; Singh, R.; Kush, P. Recent Advances in Mupirocin Delivery Strategies for the Treatment of Bacterial Skin and Soft Tissue Infection. Future Pharmacol. 2021, 1, 80-103. https:// doi.org/10.3390/futurepharmacol 1010007

Academic Editor: Daniele Ribeiro de Araujo

Received: 15 November 2021 Accepted: 16 December 2021 Published: 20 December 2021

Publisher's Note: MDPI stays neutral with regard to jurisdictional claims in published maps and institutional affiliations.

Copyright: (c) 2021 by the authors. Licensee MDPI, Basel, Switzerland. This article is an open access article distributed under the terms and conditions of the Creative Commons Attribution (CC BY) license (https:// creativecommons.org/licenses/by/ $4.0 /)$.

\begin{abstract}
Skin and soft tissue infections (SSTIs) have increased problematically in hospital and ambulatory settings due to the poor immunity of hosts and multidrug-resistant pathogens. Mupirocin (MUP), a global topical antibiotic, is used for the treatment of SSTIs caused by various pathogens due to its unique mechanism of action. However, the therapeutic efficiency of MUP is hampered due to the protein binding and drug resistance caused by frequent use. A combined report covering the various aspects of MUP, such as the synthesis of the novel formulation, loading of the drug, and application against various skin infections, is missing. This comprehensive review focuses on various novel drug delivery strategies such as composite biomaterials/scaffold, hydrogel dressings, liposomes, liposomal hydrogel, microparticles/microspheres, microsponges, nanocapsules, nanofibers, silicone-based adhesive patches, and topical sprays. The therapeutic effect of the MUP can be synergized by combining with other agents and using novel strategies. The objective is to enhance patient compliance, decrease the resistance, magnify the delivery of MUP, and overcome the limitations of conventional formulations. Moreover, the carriers/dressing materials are biocompatible, biodegradable, stimulate wound healing, protect the wound from external environmental contamination, adsorb the wound exudates, and are permeable to oxygen and moisture. This review will help researchers to explore further the treatment of various bacterial skin infections by using MUP-loaded novel formulations with better efficacy, utilizing the novel nanostructures or combinatorial methods.
\end{abstract}

Keywords: skin and soft tissue infections; mupirocin; bacterial infection; drug resistance; novel drug delivery system; magnified delivery

\section{Introduction}

The skin is the largest organ of the human body, which is daily invaded by various environmental factors such as dryness, cold bites, bacteria, fungi, and accidental fires as well. All these factors may damage skin, leading to skin and skin structure infections (SSIs) or skin and soft tissue infections (SSTIs). These are the most common type of bacterial infection that involves breaching of the integumentary part of the skin (accidental or intentional), ranging from mild severity (pyoderma) to life-threatening (necrotizing fasciitis) incidences [1-3]. In recent decades, the incidence rate of SSTIs has increased problematically in hospital and ambulatory settings in the United States due to the poor immunity of the population affected and the multidrug resistance in pathogens [4-6]. Traditionally, Staphylococcus aureus (S. aureus) and Streptococcus pyogenes (group A $\beta$-hemolytic streptococci, S. pyogenes) were the main culprits for the SSTIs, but, recently, either methicillin-resistant S. aureus (MRSA) or macrolide-resistant S. pyogenes or both in combination are the main cause of these infections [7]. SSTIs are classified in various forms based on the infection location, progression rate, clinical symptoms, causative agent, extension depth, and severity [1,7-9]. In 1998, the United States Food and Drug Administration (USFDA) categorized 
SSTIs into complicated and uncomplicated treatment. To explain further, complicated treatment addresses deeper tissue infection and requires surgical treatment and uncomplicated treatments are to cure superficial infections. However, this classification did not categorize the patients who were recovering from these infections [10]. Therefore, in 2013, the USFDA adopted a new guideline for pharmaceutical industries and classified all SSTIs into a consolidated term: acute bacterial skin and skin structure infections (ABSSSI) [2]. ABSSSI is defined as a skin bacterial infection with a lesion size of $75 \mathrm{~cm}^{2}$ area (measured by area of redness, edema, or induration), including bacterial cellulitis/erysipelas, wound infection, and cutaneous abscess [3]. This guideline excludes impetigo, minor cutaneous abscess, diabetic foot infections (DFI), infection from human or animal bites, decubitus ulcer infection, myonecrosis, necrotizing fasciitis, ecthyma gangrenosum, and chronic wound infections $[10,11]$. In 2014, the Infectious Diseases Society of America (IDSA) proposed a more relevant and practical classification of SSTIs [12]. The IDSA classified SSTIs based on "(i) skin extension, complicated infection (deep structures of the skin) and uncomplicated (superficial infections); (ii) rate of progression, acute and chronic wound infections; (iii) tissue necrosis, necrotizing and not necrotizing infections" [11]. All the classifications include the patients who possess various clinical manifestations such as cellulitis/erysipelas, wound infection, and major cutaneous abscess, etc. (Table 1) [6]. Moreover, these may be categorized into primary (bullous impetigo, cellulitis, carbuncles, furuncles impetigo contagiosa, and folliculitis), and secondary SSTIs (atopic dermatitis, prurigo, contact dermatitis, and neurodermatitis) [9].

Table 1. Descriptive details of various skin and soft tissue infections.

\begin{tabular}{|c|c|c|c|c|}
\hline SSTIs & Infection & Pathogen & Description & Ref. \\
\hline \multirow{4}{*}{ Non-purulent SSTIs } & Impetigo & $\begin{array}{l}\text { Staphylococcus aureus, } \\
\text { Streptococcus pyogenes }\end{array}$ & $\begin{array}{l}\text { Superficial infection developed via } \\
\text { direct or indirect invasion of bacteria. It } \\
\text { is the most common infection in } \\
\text { children and presents in two forms, i.e., } \\
\text { bullous and non-bullous impetigo. }\end{array}$ & {$[7,9,13]$} \\
\hline & Cellulitis & $\begin{array}{c}\text { Staphylococcus aureus, } \\
\text { beta-hemolytic } \\
\text { streptococci (groups A, B, } \\
\text { C, or G) }\end{array}$ & $\begin{array}{l}\text { Subcutaneous infections are } \\
\text { accompanied by lymphadenopathy and } \\
\text { lymphangitis. It is characterized by } \\
\text { redness, edema, or induration and } \\
\text { usually affects lower limbs. }\end{array}$ & [7] \\
\hline & Erysipelas & $\begin{array}{l}\text { Staphylococcus aureus, } \\
\text { Streptococcus pyogenes }\end{array}$ & $\begin{array}{l}\text { Superficial lymphatics and upper } \\
\text { dermis infection, usually affects the face } \\
\text { and sometimes lower limbs. It possesses } \\
\text { well-defined sharp raised borders in } \\
\text { contrast to non-infected areas. }\end{array}$ & {$[7,13]$} \\
\hline & Folliculitis & $\begin{array}{l}\text { Pseudomonas aeruginosa, } \\
\text { Staphylococcus aureus, } \\
\text { Streptococcus pyogenes }\end{array}$ & $\begin{array}{l}\text { It is a superficial inflammation of hair } \\
\text { follicles, mainly affecting moist skin } \\
\text { with hair. }\end{array}$ & {$[7,9,14]$} \\
\hline \multirow[b]{2}{*}{ Purulent SSTIs } & Furuncle & Staphylococcus aureus & $\begin{array}{l}\text { Furuncle or boil is a deep inflammatory } \\
\text { infection developed from folliculitis. } \\
\text { Initially, it is a firm, tender, } \\
\text { erythematous nodule that becomes } \\
\text { fluctuant and painful. It usually infects } \\
\text { the face, buttocks, and axillae. }\end{array}$ & {$[9,13]$} \\
\hline & Carbuncle & $\begin{array}{l}\text { Staphylococcus aureus, } \\
\text { Streptococcus pyogenes }\end{array}$ & $\begin{array}{l}\text { It is an aggregation of multiple } \\
\text { furuncles, involves infection of the hair } \\
\text { follicle, and is further extended to } \\
\text { subcutaneous tissues. The infection is } \\
\text { painful and tender but the patient is } \\
\text { well. It is usually observed at the neck, } \\
\text { back, and thighs. }\end{array}$ & {$[7,9,13]$} \\
\hline
\end{tabular}


Table 1. Cont.

\begin{tabular}{|c|c|c|c|c|}
\hline SSTIs & Infection & Pathogen & Description & Ref. \\
\hline & Abscess & $\begin{array}{l}\text { Staphylococcus aureus, } \\
\text { Streptococcus pyogenes, } \\
\text { Streptococcus milleri, } \\
\text { viridans, streptococci, } \\
\text { coagulase-staphylococci }\end{array}$ & $\begin{array}{l}\text { Focal collection of pus in dermis and } \\
\text { hypodermis, characterized by tender, } \\
\text { red nodules surrounded by } \\
\text { erythematous swelling. }\end{array}$ & {$[7,9,15,16]$} \\
\hline \multirow[t]{2}{*}{ Complex SSTIs } & Burn wound & Anaerobes & $\begin{array}{l}\text { Burn wound infection possesses a high } \\
\text { bacteria concentration ( }>10^{5} \text { colonies } \\
\text { forming unit). It arises immediately } \\
\text { after the injury due to the damage of the } \\
\text { cutaneous barrier and adaptive } \\
\text { immunity. The surrounding tissues of } \\
\text { the burn wound exhibit warmth, } \\
\text { tenderness, induration, and erythema. }\end{array}$ & {$[6,17]$} \\
\hline & $\begin{array}{l}\text { Surgical site } \\
\text { infection }\end{array}$ & Escherichia coli & $\begin{array}{l}\text { It usually arises } 4 \text { days after surgery and } \\
\text { is categorized into superficial incisional, } \\
\text { deep incisional, and organ or space } \\
\text { infection. It is diagnosed by incisional } \\
\text { discharge, swelling, tenderness, } \\
\text { and erythema. }\end{array}$ & [18] \\
\hline $\begin{array}{l}\text { Diabetic foot } \\
\text { infection }\end{array}$ & & $\begin{array}{l}\text { Staphylococcus aureus, } \\
\text { Enterococci, } \\
\text { Pseudomonas aeruginosa, } \\
\text { Enterobacteriaceae, } \\
\text { Acinetobacter spp., } \\
\text { Bacteroides spp. }\end{array}$ & $\begin{array}{l}\text { This infection is most common in } \\
\text { diabetic patients and possesses high } \\
\text { mortality. This infection encompasses a } \\
\text { range from nails to necrotizing limbs. } \\
\text { Nails serve as an entry portal for } \\
\text { bacterial infection due to poor hygiene. }\end{array}$ & {$[6,19,20]$} \\
\hline Necrotizing SSTIs & $\begin{array}{l}\text { Monomicrobial, } \\
\text { Polymicrobial }\end{array}$ & $\begin{array}{c}\text { Staphylococcus aureus, } \\
\text { Streptococcus pyogenes } \\
\text { Gram-negatives, } \\
\text { Clostridium species, } \\
\text { Anaerobic bacteria }\end{array}$ & $\begin{array}{l}\text { Necrosis of soft tissues or muscles is } \\
\text { initially characterized by erythema and } \\
\text { induration with pain followed by skin } \\
\text { color change to blue/purple. The } \\
\text { patient suffers from systemic toxicity, } \\
\text { multi-organ failure, and } \\
\text { hemodynamic instability. }\end{array}$ & {$[6,7,9]$} \\
\hline Bite wounds & $\begin{array}{l}\text { Human and } \\
\text { animal bite }\end{array}$ & $\begin{array}{c}\text { Eikenella corrodens, } \\
\text { Pasteurella multocida, } \\
\text { Pasteurella canis, } \\
\text { Capnocytophaga } \\
\text { canimorsus, } \\
\text { Staphylococcus aureus }\end{array}$ & It usually arises after biting. & {$[7,21,22]$} \\
\hline
\end{tabular}

SSTIs can be complicated when Gram-negative bacteria accumulate in highly risky areas, such as the rectum, and invade deeper skin areas. Therefore, a systemic approach is required for the optimal management of complicated SSTIs. Optimal management initially comprises physical examination followed by identification of pathogen via a smear of discharge from the lesions. Further, based on culture and susceptibility results, adequate antibacterial therapy should be implemented [19]. Topical antibiotics are an extensively used therapy for the management of SSTIs due to their capability to provide higher concentration to the target area with minimized adverse effects. Additionally, the topical application offers various advantages in contrast to systemic administration, such as patient compliance and regular inspection of infection, and allows the use of such therapeutic agents (bacitracin or neomycin) that can not be systematically administered. Clinically, various topical antibiotics, such as bacitracin, neomycin, polymyxin B, fusidic acid, and mupirocin (MUP), are currently used for the treatment of SSTIs [23].

MUP is one of the widely used topical antibiotics that is effectively used to treat superficial skin infections caused by Gram-positive and Gram-negative bacteria, especially 
nasal MRSA due to its broad antibacterial spectrum [23-25] and antibiofilm property [18,26]. Commercially, MUP (2\%) is available as cream and ointments (Bactroban, Bactoderm, Mupirocin, Turixin) [24]. Due to the unique mechanism of action, it does not possess any cross-resistance with other antibiotics, leading to global use in various hospital departments. However, the potential efficacy of MUP is hampered due to its short half-life $(<30 \mathrm{~min})$, high protein binding, and different resistance rates (1-81\%) [23,24,27]. Furthermore, the conventional formulations possess some adverse effects such as burning, dryness, itching, rashes, redness, nausea, pain, stinging, swelling, or tenderness [18]. The purpose of this paper is to review the clinical status of MUP for the management of bacterial skin infection and then provide more comprehension on various drug delivery strategies to augment MUP delivery and overcome the limitations of the conventional formulation.

\section{Mupirocin: A Drug of Choice for the Treatment of Skin Infection}

MUP $\left(\mathrm{C}_{26} \mathrm{H}_{44} \mathrm{O}_{9}\right)$ is one of the first drugs which was synthesized by the modular polyketide synthases and isolated from soil bacteria Pseudomonas fluorescens NCIMB 10586. This unique polyketide topical antibiotic is a mixture of four pseudomonic acids (A-D) and is composed of monic acid and 9-hydroxynonanoic acid (Figure 1). It is a welltolerated topical antibiotic owing to its minimal systemic absorption through intact skin [24]. Additionally, it exhibits poor in vitro antibacterial activity against the normal skin defense flora (e.g., Corynebacterium, Micrococcus, and Propionibacterium). Multiple studies revealed that topical MUP was more effective for the treatment of impetigo in contrast to various systemic antibiotics (ampicillin cloxacillin, cephalexin, dicloxacillin, erythromycin, and flucloxacillin) [28]. However, it is not recommended for systemic administration due to in vivo degradation into an inactive metabolite (monic acid) and high protein binding [27].

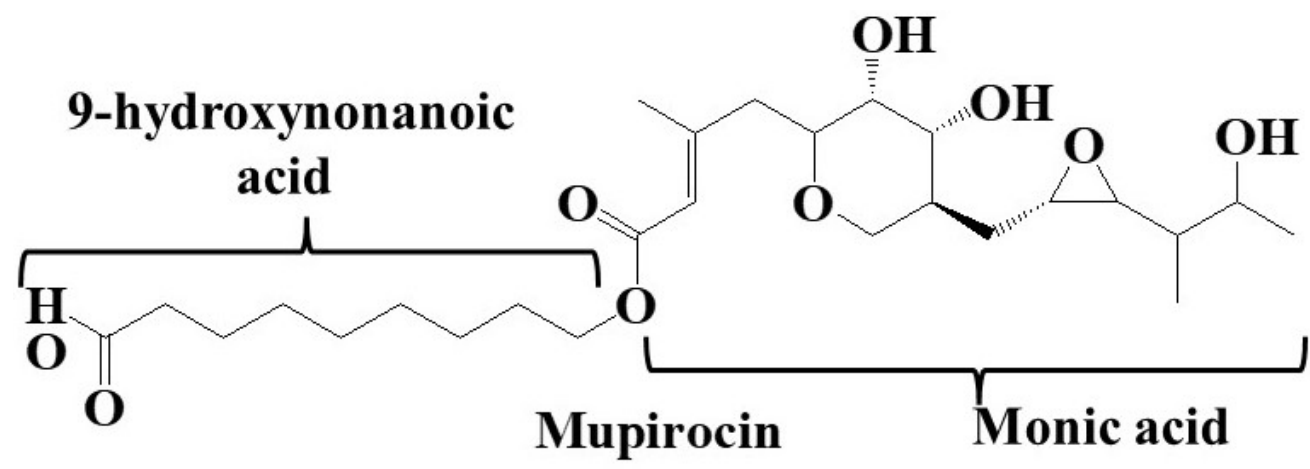

Figure 1. Mupirocin structure encompasses monic acid (a heptaketide) with pyran ring connected to the 9-hydroxynonanoic acid via an ester linkage.

\subsection{Clinical Application and Mechanism of Action}

MUP is mainly used to treat primary and secondary skin infections, skin appendages [29], peritonitis [30], nasal, and mucus membrane infections [31] caused by S. aureus and S. epidermidis, including MRSA and beta-lactamase-producing strains. Clinically, it exhibits approximately $80 \%$ improvement in infected patients and $90 \%$ abolishment in S. aureus isolates [32]. Moreover, it can also prevent the colonization of MRSA in health care professionals, intensive care units (ICU), dialysis units, and cardiothoracic and orthopedic surgery wards [28]. Decolonization can decrease the risk of MRSA infections in patients and reduce the transmission to other patients [33]. Furthermore, clinical studies revealed that monotherapy with MUP $2 \%$ ointment was effective for the treatment of erythrasma [34] and Zoon's balanitis [35]. Additionally, MUP-loaded nanoliposomes were used for the treatment of multidrug-resistant Neisseria gonorrhoeae [27].

It reversibly binds to the isoleucine (Ile)-binding site of the isoleucyl-transfer RNA (Ile-tRNA) synthetase enzyme, which catalyzes the formation of Ile-tRNA from Ile and $\mathrm{t}$-RNA. This enzyme complex prevents Ile incorporation into the protein chains, leading to inhibiting RNA and protein synthesis (Figure 2) [36]. This peculiar mechanism of action 
is due to the similarity between the one moiety of MUP (C-14 and C-11 of monic acid) and Ile. It does not possess any cross-resistance with other antibiotics owing to its unique mechanism of action [23].

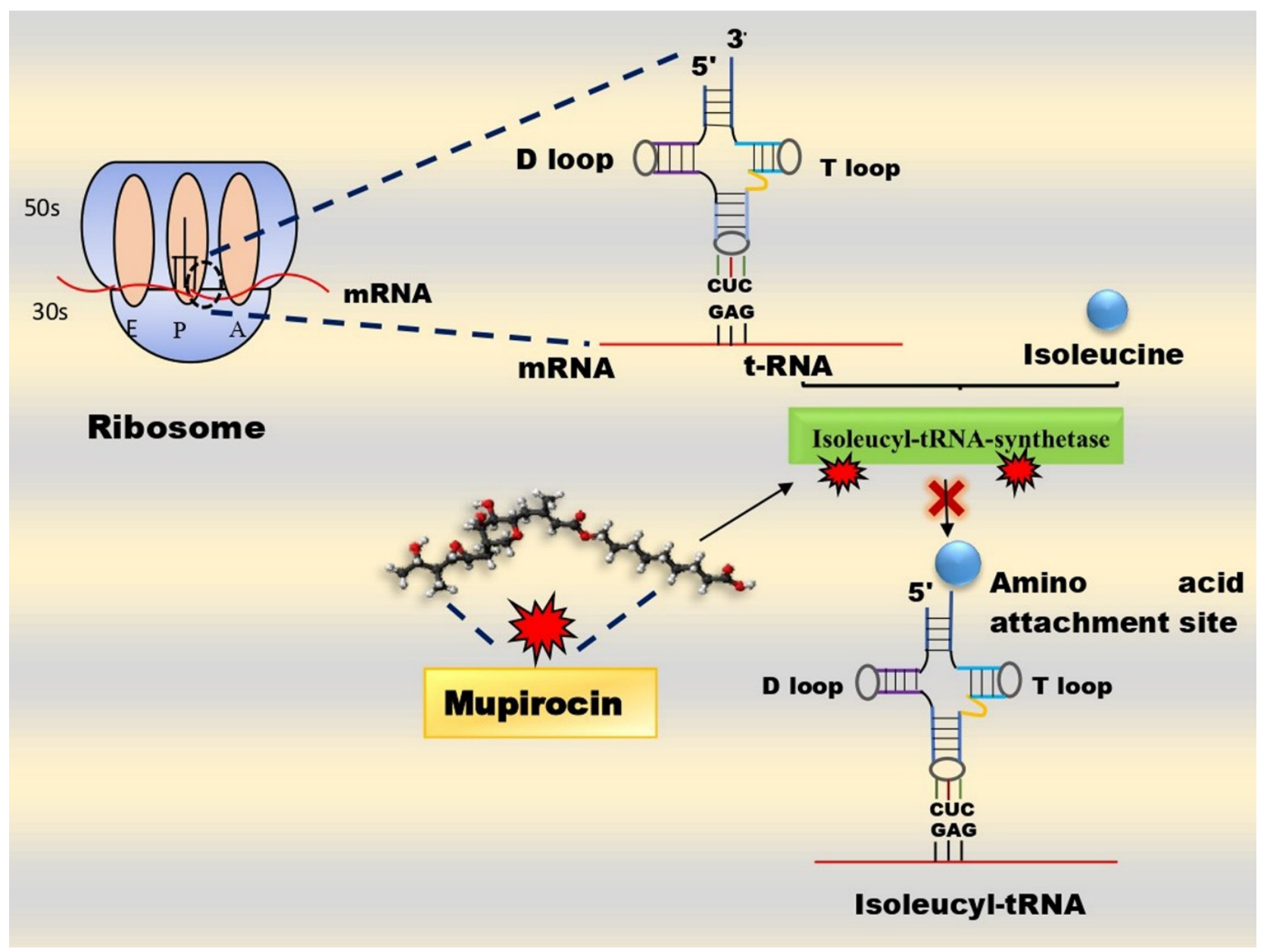

Figure 2. Unique mechanism of action of mupirocin.

MUP exhibits a bacteriostatic property at low concentration but possesses bactericidal activity after $24 \mathrm{~h}$ of topical application $(20,000 \mu \mathrm{g} / \mathrm{mL}$ with $2 \%$ formulation) [28]. Moreover, the antibacterial property is $\mathrm{pH}$-dependent, i.e., at acidic $\mathrm{pH}$, it displays magnified in vitro antibacterial activity, so the low $\mathrm{pH}$ of the skin provides a favorable environment for effective treatment [24,28].

\subsection{Drug Resistance: More Than a Challenge}

The first MUP-resistant S. aureus was reported in 1987 during MRSA treatment at St. Thomas' hospital, London [32,33]. The MUP resistance frequency varies (0-65\%) in different MRSA strains. Globally, MUP resistance is increasing in the S. aureus species, especially MRSA, due to an increase in over-the-counter, unjustified, and long-term usage, leading to the potential efficacy being hampered. The prevalence of MUP resistance in $S$. aureus depends on various factors such as selection of patient population (community, hospital, or ICU), surveillance nature, e.g., active surveillance in previously MUP-treated patients vs. passive surveillance of isolates from all the patients, and associated resistance profile. Based on the minimum inhibitory concentration (MIC), MUP possesses two types of resistance: low-level resistance (LLR) and high-level resistance (HLR). LLR (MIC $\leq 8-256 \mu \mathrm{g} / \mathrm{mL}$ ) is a more common chromosomal resistance that usually arises due to the spontaneous point mutation of the Ile-tRNA synthetase gene, leading to the retardation of the binding 
affinity of MUP to the Ile-tRNA synthetase enzyme [23]. LLR resistance is clinically insignificant and non-transferable, but further mutations can lead to HLR via the acquisition of a pSK41-like plasmid (staphylococcal multi-resistant conjugative plasmids) [32,33,37]. HLR (MIC $>500 \mu \mathrm{g} / \mathrm{mL}$ ) is a plasmid-coded resistance that possesses two resistance mechanisms. The first mechanism comprises the acquisition of plasmid-mediated mupA or the Ile-tRNA synthetase-2 gene [32]. Moreover, the mupA gene is self-transmissible, leading to creating resistance to other antibiotics such as clindamycin, erythromycin, gentamicin, tetracycline, levofloxacin, and trimethoprim $[33,38]$. Molecular studies revealed that the mupA gene is mainly responsible for HLR in almost all S. aureus isolates. The second mechanism is due to the synthesis of another paralog тирB that shares $45.5 \%$ sequence identity with Ile synthetase and $65.5 \%$ identity with mupA. Additionally, some aminoacyl-tRNA synthetases paralogs are also responsible for MUP resistance $[24,38]$.

\section{Novel Strategies to Augment Mupirocin Delivery in Bacterial Skin Infection}

Though MUP is used for the treatment of various bacterial skin infections, it possesses certain limitations such as a short half-life, high protein binding, and drug resistance $[23,27]$. The resistance can be overcome by the controlled use of MUP for the target decolonization, limiting the treatment duration up to 10 days, and not repeating the treatment for up to 30 days minimum. Further, the antibacterial effect of the MUP can be synergized by combining with other agents such as anesthetics, other topical antibiotics, and natural herbs. Thus, various novel drug delivery strategies have been adopted to enhance patient compliance, decrease the resistance, magnify the delivery of mupirocin, and overcome the limitations of conventional formulations. In this section, various novel formulations such as composite biomaterials/scaffold, hydrogel dressings, liposomes, liposomal hydrogel, microparticles/microspheres, microsponges, nanocapsules, nanofibers, topical sprays, nanostructured lipid carriers, and silicone-based adhesive patches, etc., will be discussed (Table 2). 
Table 2. Various mupirocin-loaded drug delivery systems for the treatment of skin and soft tissue infections.

\begin{tabular}{|c|c|c|c|c|c|}
\hline Drug Delivery System & Infection & Pathogen & Biomaterial & Outcome & Ref. \\
\hline \multirow[b]{2}{*}{$\begin{array}{l}\text { Composite } \\
\text { biomaterials/scaffold }\end{array}$} & \multirow[b]{2}{*}{ Wound healing } & \multirow[b]{2}{*}{$\begin{array}{l}\text { Staphylococcus aureus, Bacillus } \\
\text { subtilis, Escherichia coli }\end{array}$} & \multirow[b]{2}{*}{ Collagen, Silica } & $\begin{array}{c}\text { The collagen scaffolds exhibited more therapeutic } \\
\text { potential for the treatment of wound infection and } \\
\text { displayed a promising carrier approach for tissue } \\
\text { engineering. }\end{array}$ & [39] \\
\hline & & & & $\begin{array}{l}\text { The developed bio-composite exhibited enhanced water } \\
\text { uptake, sustained release, and antimicrobial activity. } \\
\text { In vivo results stipulated that the biomaterial showed } \\
\text { enhanced adhesion and wound contraction rate, } \\
\text { supported by histopathological analysis. }\end{array}$ & [40] \\
\hline \multirow{5}{*}{ Hydrogel dressings } & Wound healing & $\begin{array}{c}\text { Escherichia coli } \\
\text { (ATCC 8739), Enterococcus hirae } \\
\text { (ATCC 10541), S. aureus } \\
\text { (ATCC 6538), Pseudomonas } \\
\text { aeruginosa (ATCC 27853), Bacillus } \\
\text { cereus (ATCC 7064), Klebsiella } \\
\text { pneumonia }\end{array}$ & $\begin{array}{l}\text { Chitosan, sodium alginate, } \\
\text { carbopol }\end{array}$ & $\begin{array}{l}\text { The developed composite film accelerated the } \\
\text { regeneration of the epidermal layer in contrast to the } \\
\text { marketed commercial formulation. }\end{array}$ & [41] \\
\hline & Diabetic wound & & Polyvinyl alcohol & $\begin{array}{l}\text { The developed gel was effective for the treatment of } \\
\text { diabetic wound and accelerated the wound closure. }\end{array}$ & [42] \\
\hline & Primary and secondary & $\begin{array}{l}\text { Gram-positive and Gram-negative } \\
\text { bacteria }\end{array}$ & Chitosan & $\begin{array}{c}\text { The prepared polymeric membrane was spherical, stable, } \\
\text { and elastic, along with having the controlled release } \\
\text { property. Furthermore, the membrane exhibited } \\
\text { magnified retention of the drug in the skin without any } \\
\text { irritation. }\end{array}$ & [43] \\
\hline & Surgical wound & Staphylococcus aureus & Chitosan & $\begin{array}{l}\text { The formulated spherical membrane exhibited superior } \\
\text { adhesion and elasticity along with progressive drug } \\
\text { release. The Draize patch test revealed that the developed } \\
\text { membrane was non-irritant to the skin, along with } \\
\text { having magnified antimicrobial efficiency and enhanced } \\
\text { retention to the skin. }\end{array}$ & [44] \\
\hline & Skin injuries & & Acrylic acid & $\begin{array}{l}\text { The developed patches exhibited good elasticity and } \\
\text { tensile strength, along with enhanced permeation and } \\
\text { retention into the skin. The patches were non-irritant to } \\
\text { the skin, evidenced by the Draize patch test. }\end{array}$ & [45] \\
\hline
\end{tabular}


Table 2. Cont.

\begin{tabular}{|c|c|c|c|c|c|}
\hline Drug Delivery System & Infection & Pathogen & Biomaterial & Outcome & Ref. \\
\hline Liposomes & & $\begin{array}{l}\text { Methicillin-resistant } \\
\text { Staphylococcus aureus (MRSA), } \\
\text { Staphylococcus aureus }\end{array}$ & $\begin{array}{l}\text { Hydrogenated soy } \\
\text { phosphatidylcholine, } \\
\text { 1,2-distearoyl-sn-glycero-3- } \\
\text { phosphoethanolamine-N- } \\
\text { [methoxy (PEG)-2000], } \\
\text { cholesterol }\end{array}$ & $\begin{array}{l}\text { Mupirocin was administered intravenously the first time } \\
\text { with a distinctive mechanism of action that resulted in a } \\
\text { better approach for the treatment of resistant bacterial } \\
\text { infection. Further, the results stipulated that } \\
\text { nano-mupirocin extended the topical application of } \\
\text { mupirocin to the systemic application for the treatment of } \\
\text { MRSA infections by changing the pharmacodynamics of } \\
\text { mupirocin. }\end{array}$ & [46-48] \\
\hline Liposomal hydrogel & Burn therapy & $\begin{array}{c}\text { Staphylococcus aureus and } \\
\text { Bacillus subtilis }\end{array}$ & Chitosan & $\begin{array}{l}\text { Mupirocin-loaded liposomal hydrogel system exhibited } \\
\text { prolonged release and superior bio-adhesiveness in } \\
\text { contrast to the marketed formulation of mupirocin. } \\
\text { In vitro and in vivo studies stipulated that the developed } \\
\text { system was significantly safe, more therapeutically active } \\
\text { along with shorter healing time, and exhibited } \\
\text { antibiofilm activity against the bacterial pathogen. }\end{array}$ & {$[49,50]$} \\
\hline $\begin{array}{l}\text { Microparticles/ } \\
\text { Microspheres }\end{array}$ & Wound healing & Staphylococcus aureus & Eudragit & $\begin{array}{l}\text { The developed formulation exhibited the sustained } \\
\text { release of mupirocin along with magnified storage. The } \\
\text { morphology, drug release, and antimicrobial activity of } \\
\text { the developed formulation were dependent on the drug } \\
\text { loading and the solvent. Time-kill assay results revealed } \\
\text { that there was no loss of the antimicrobial activity of } \\
\text { mupirocin during the encapsulation. }\end{array}$ & {$[51,52]$} \\
\hline \multirow[b]{2}{*}{ Microsponges } & Surgical wound & Staphylococcus aureus & Ethylcellulose & $\begin{array}{l}\text { Mupirocin microsponge exhibited a diffusion-controlled } \\
\text { release profile along with } \sim 5 \text { times magnified retention on } \\
\text { rat skin in contrast to the marketed formulation. The } \\
\text { formulation was found stable and non-irritant, evidenced } \\
\text { by the Draize patch test. }\end{array}$ & [53] \\
\hline & Wound healing & $\begin{array}{c}\text { Staphylococcus aureus, } \\
\text { Escherichia coli }\end{array}$ & Keratin, fibrin, and gelatin & $\begin{array}{l}\text { The developed formulation exhibited a prolonged release } \\
\text { pattern along with enhanced biocompatibility and cell } \\
\text { adhesion properties. The antimicrobial activity results } \\
\text { demonstrated that the mupirocin-loaded sponge was a } \\
\text { promising medicated dressing material for the treatment } \\
\text { of wound infection. }\end{array}$ & [54] \\
\hline
\end{tabular}


Table 2. Cont.

\begin{tabular}{|c|c|c|c|c|c|}
\hline Drug Delivery System & Infection & Pathogen & Biomaterial & Outcome & Ref. \\
\hline \multirow[b]{3}{*}{ Nanocapsule/nanoparticles } & \multirow[b]{3}{*}{ Wound healing } & & Poly(E-caprolactone) & $\begin{array}{l}\text { The developed nanocapsules showed excellent stability at } \\
\qquad 40^{\circ} \mathrm{C} \text { and room temperature. }\end{array}$ & [55] \\
\hline & & $\begin{array}{c}\text { Methicillin-resistant } \\
\text { Staphylococcus aureus (MRSA) }\end{array}$ & Chitosan, selenium & $\begin{array}{l}\text { The tailored formulation showed remarkable therapeutic } \\
\text { potential in terms of diabetic wound healing and wound } \\
\text { contraction compared to the native mupirocin. }\end{array}$ & [56] \\
\hline & & $\begin{array}{c}\text { Staphylococcus aureus, } \\
\text { Staphylococcus epidermidis, } \\
\text { Pseudomonas aeruginosa, and } \\
\text { Escherichia coli }\end{array}$ & $\begin{array}{l}\text { Poly(ethylene oxide)-poly } \\
\text { (propylene } \\
\text { oxide)-poly(ethylene oxide) } \\
\text { (PEO-PPO-PEO) }\end{array}$ & $\begin{array}{l}\text { The tailored formulation exhibited reduced minimum } \\
\text { inhibitory concentrations and minimum bactericidal } \\
\text { concentrations against } S \text {. aureus, S. epidermidis, } \\
\text { Pseudomonas aeruginosa, and E. coli compared to the } \\
\text { mupirocin ointment. Further, the developed formulation } \\
\text { was safe, effective, and biocompatible for the treatment of } \\
\text { wound infection. }\end{array}$ & {$[57,58]$} \\
\hline \multirow[b]{2}{*}{ Nanofibers } & Wound healing & Staphylococcus aureus & Poly-1-lactic acid & $\begin{array}{l}\text { The tailored scaffold exhibited a different release profile } \\
\text { for both drugs, suggesting that the release kinetics of one } \\
\text { drug was altered by keeping the two different drugs in } \\
\text { the same polymer matrix. The dual drug scaffold released } \\
\text { a significantly higher drug and even compensated the } \\
\text { inactive monic acid to act on the applied area, resulting in } \\
\text { the maintainence of a sufficient concentration of } \\
\text { mupirocin in the infected wound for more than a } 72 \mathrm{~h} \\
\text { period, resulting in profound wound healing. }\end{array}$ & [59] \\
\hline & Burn wound & $\begin{array}{l}\text { Staphylococcus aureus, Pseudomonas } \\
\text { aeruginosa, and Escherichia coli }\end{array}$ & Polyurethane & $\begin{array}{l}\text { The developed fiber mat was enough for wound } \\
\text { hydration via providing adequate environmental } \\
\text { humidity. Moreover, the tailored nanofiber exhibited } \\
\text { sufficient cell spreading and attachment. The cytotoxicity } \\
\text { results revealed that the antibacterial activity of the } \\
\text { scaffold was increased proportionally with the increase in } \\
\text { mupirocin concentration ( } 2-5 \%) \text {. Further, the } \\
\text { histopathological study revealed that the nanofibrous } \\
\text { mat was enough for burn wound healing due to } \\
\text { negligible inflammation. }\end{array}$ & {$[60]$} \\
\hline
\end{tabular}


Table 2. Cont.

The tailored multifunctional double-layer nanofibrous scaffold (MDLS) was effective for the management of

Staphylococcus aureus, Pseudomonas aeruginosa, and Escherichia coli

Polycaprolactone

\section{Staphylococcus aureus, and}

Escherichia coli Keratin, and coenzyme Q10,
and polyvinyl alcohol wound infection, along with superior tensile strength

with enhanced contact angle and swelling ratio.

Furthermore, cytotoxicity results revealed that the MDLS was more biocompatible due to the addition of chitosan in contrast to polycaprolactone nanofibers.

The tailored formulations were biocompatible, evidenced by the skin irritancy test. Further, the therapeutic efficacy of the tailored formulation was assessed by antimicrobial of the tailored formulation was assessed by antimicrobia 2587, 2590), MRSA 2555, and E. coli 1808. Moreover, cell proliferation results evidenced the ability of nanofibers to support the keratinocytes' growth due to the presence of coenzyme Q10.

The developed spray exhibited magnified antimicrobial activity (18-fold) against $S$. suis, in contrast to the

marketed formulation due to close contact between spray and skin, leading to the formation of a thin film on the infected surface. Moreover, the topical formulation was

Topical spray

Burn wound

Staphylococcus aureus, Pseudomonas aeruginosa, and Escherichia coli, and

Streptococcus suis (S. suis)

Eudragit E100

found non-irritant to the human skin without any toxicity

to the monocytes, keratinocytes, and fibroblasts cells. Additionally, the safety profile of the formulation was also confirmed by zero production of nitric oxide and inflammatory cytokines (IL-1b and TNF-a) due to its antiendotoxin effect.

Nanostructured lipid carrier
Cetyl palmitate

caprylic acid
Nanostructured lipid carrier (NLC) reduced the metabolic degradation of MUP via the protective lipid layer of NLC which resulted in a 40-fold and 55-fold area under the curve and half-life, respectively, in contrast to native MUP. 


\subsection{Composite Materials/Scaffolds}

A composite material comprises a synergistic approach by combining two or more materials to achieve a novel material possessing the specific properties not manifested by the individual components [65]. There are various types of composite materials based on their reinforcement and matrix orientation. These materials are widely used in various fields, including civil construction, aerospace, aeronautics, and automotive and biomedical application. Biomedical applications include cardiovascular, dentistry, oral, skin infections, and tissue engineering due to their biocompatibility, biodegradability, porosity, and tissue regeneration capacity $[66,67]$.

Inspired by this approach, Ramadass et al. fabricated MUP-loaded collagen hydrolysate composite scaffold (CHCS) by sol-gel process for the treatment of wound infection [39]. Collagen hydrolysate, the daughter fragment of collagen, was used as a better alternative to the conventionally used collagen due to enhanced solubility accompanied by better bioavailability [68]. Collagen is a three-dimensional biomaterial that plays a vital role in the treatment of various purulent and non-purulent skin infections, such as burns, pressure sores, wounds, legs, and decubitus ulcers, but possesses some drawbacks such as multistep extraction, which increases the cost, restricted solubility, low porosity, and faster collagen turnover $[39,69]$. The CHCS was prepared by the sol-gel process, using tetraethoxysilane as the silica precursor. Porosity and stability were the main reasons for the magnified adsorption of the water present in the exudate, resulting in the encouragement of autolytic debridement of the wound infection [70]. Further, the CHCS scaffold was found more biostable in contrast to the collagen with a minimum frequency of dressing change. The in vitro drug release results suggested that the MUP was released in a sustained manner over $(\sim 88.14 \pm 6.21 \%)$ more than $72 \mathrm{~h}$ due to the CHCS scaffold. The antimicrobial study revealed that the CHCS exhibited enhanced activity against the used pathogens, S. aureus, Bacillus subtilis (B. subtilis), Pseudomonas aeruginosa (P. aeruginosa), and Escherichia coli (E. coli), due to the synergistic effect of MUP and collagen hydrolysate. Additionally, in vivo studies on the rat model revealed that the tailored formulation healed the infection better than the conventional formulation, hence omitting frequent dressing. Thus, MUP-loaded CHCS offers an alternative and cost-effective alternative for wound treatment [39].

In another study, Perumal et al. synthesized a bio-composite by combining MUP as an antimicrobial, silica microspheres as a drug delivery carrier, and collagen as a wound healer. The synthesis of the bio-composite involved a two-step process: (1) synthesis of MUP-loaded silica microspheres by the sol-gel process (MUP-SM) and (2) incorporation of MUP-SM into collagen solution (MUP-SM incorporated collagen scaffold) (Figure 3). The MUP-SM-incorporated collagen scaffold delivered $81.65 \pm 5.02 \%$ MUP for up to 3 days, in contrast to MUP incorporated into the collagen scaffold ( $88.01 \pm 2.01 \%, 1$ day). This sustained release was due to the silica microspheres, leading to maintaining the drug concentration for a longer time and reducing the frequency of drug application which will be beneficial to combat the wound infection cost-effectively. Furthermore, magnified water uptake, tensile strength, cell proliferation, and antimicrobial assay revealed the efficacy of the developed formulation. Additionally, wound closure analysis stipulated that the complete epithelialization was at $14.2 \pm 0.44$ days for MUP-SM-loaded collagen, whereas it was at $17.4 \pm 0.44$ days and $20.6 \pm 0.54$ days for collagen and control groups, respectively. This enhanced efficacy was due to the synergistic effect of MUP-SM and collagen scaffold protecting against the microbial invasion to the wound and tissue regeneration facilitation, respectively. Histopathological analysis revealed better dermal collagenization and fibroblast proliferation. In conclusion, this combined strategy exhibited a sustained-release property and better adhesion, along with enhanced wound contraction rate. Thus, it would be a better approach for the augmented delivery of MUP for the treatment of various skin infections [40]. 


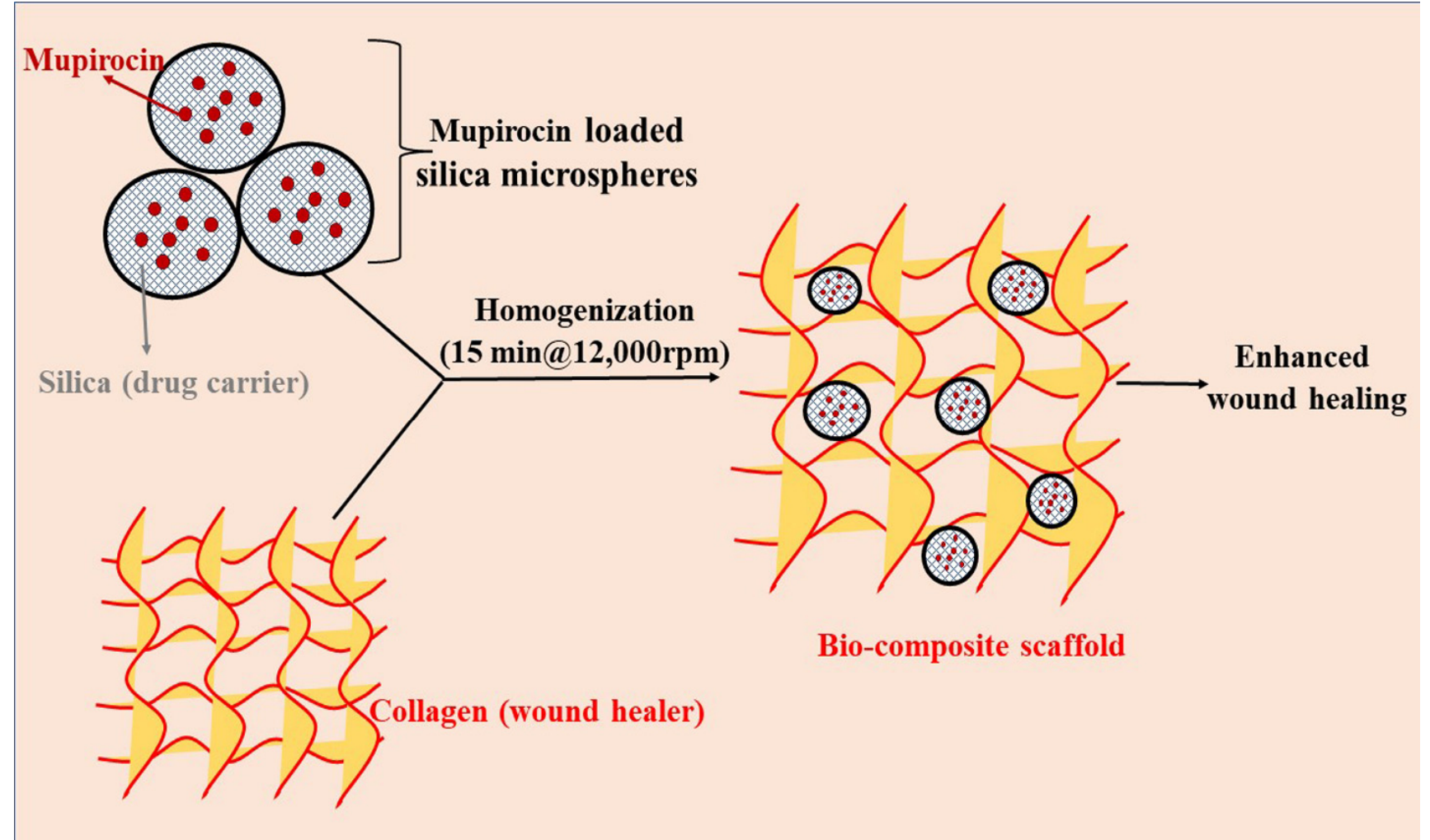

Figure 3. A synergistic bio-composite scaffold comprises mupirocin-loaded silica microspheres embedded in the wound healer collagen scaffold, enabling enhanced wound healing.

\subsection{Hydrogel Membrane}

Hydrogels are hydrophilic, porous, three-dimensional, cross-linked, macromolecular polymeric networks, stabilized chemically or physically via interlinkage in their lattice structure $[45,71]$. They have been extensively used for topical application as an alternative material due to their durability, elasticity, biocompatibility, biodegradability, and adhesiveness. Due to their inherent hydrophilicity, hydrogels can absorb an enormous number of biological fluids or water, which makes them a soft material. These structures can imitate the mechanical properties of various animal tissues and revive the actual extracellular matrix, leading to the promising carrier for regenerative medicine [72]. Furthermore, various forms of hydrogels are also used in drug delivery and tissue engineering (Figure 4).

Okur et al. developed and optimized various natural polymer-based (chitosan, sodium alginate, and carbomer) hydrogel dressings by using the solvent casting method. All the formulations exhibited a spherical shape, magnified drug content with an improved in vitro drug release profile, and permissible thickness for the wound dressing. Antimicrobial activity and ex vivo bio-adhesion study revealed that the developed formulation possessed superior antibacterial activity and could be safely applied to the infected area without causing any skin irritation. Furthermore, in vivo studies concluded that the developed film was more effective for wound healing as it accelerated the regeneration of the epidermal layer, in contrast to the marketed commercial formulation (Bactroban cream; GlaxoSmithKline, Turkey), due to its unique physicochemical properties [41]. Recently, a MUP-loaded polyvinyl alcohol (PVA)-based hydrogel cross-linked by a reactive oxygen species (ROS) responsive linker was developed by Zhao et al. The developed ROS-scavenging hydrogel was able to treat the bacterially infected diabetic wound and accelerated the wound closure due to the loading of MUP and granulocyte-macrophage colony-stimulating factor (GM-CSF), respectively [42]. 


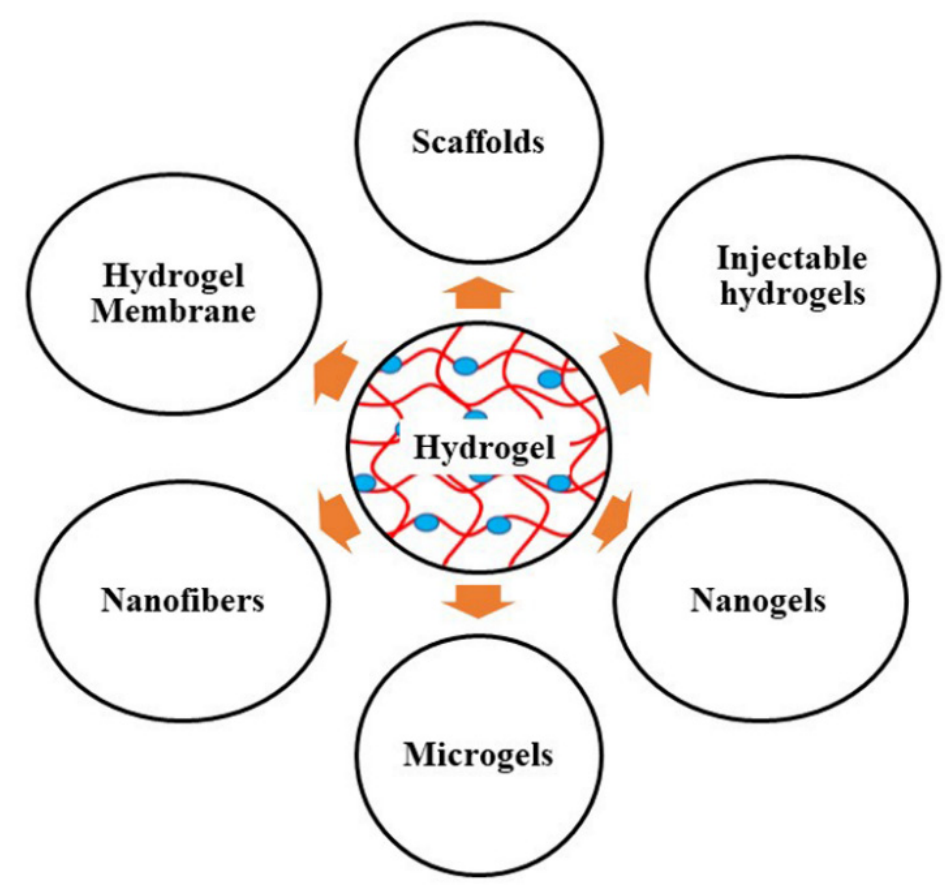

Figure 4. Various types of hydrogels used in drug delivery and tissue engineering.

A hydrogel membrane (HM) possesses the permeability and porosity of a thin membrane, along with the mechanical, elastic, and hydrophilic properties of the hydrogel. HMs are of great interest for the treatment of skin infection due to their hydrating nature, non-irritability to the adjacent tissues, lower interfacial tension, and enhanced oxygen permeability [73-75]. Ahmad et al. fabricated MUP-loaded chitosan-based HM for the treatment of primary and secondary skin infections by using radical polymerization techniques. The MUP-loaded chitosan-based HM exhibited magnified retention of the MUP in the skin without any irritation in comparison to the marketed formulation (MUPIR) [43]. This enhanced retention was due to the interaction of the cationic chitosan and hydrophobic moiety of MUP with the negative charge of the skin [76]. Further, Sarfaraz Ahmad et al. prepared another MUP-loaded low-molecular-weight chitosan-based HM by using the same method. The formulated spherical HM exhibited superior adhesion and elasticity, along with progressive drug release. The Draize patch test revealed that the developed membrane was non-irritant to the rabbit skin, along with having magnified antimicrobial efficiency against $S$. aureus on the rat's skin. The developed MUP-loaded HM exhibited enhanced retention of MUP in the skin in contrast to commercial ointment, leading to patient compliance and better efficacy with a lower frequency of topical application [44].

In another study, an acrylic, acid-based topical patch was prepared for the controlled release application of MUP by using a modified, aqueous-based polymerization technique. These hydrogel patches were prepared by cross-linking acrylic acid with 2-acrylamido-2methylpropane sulfonic acid by using $\mathrm{N}, \mathrm{N}$-methylenebisacrylamide as a crosslinker. The developed patches were spherical, thick, and elastic, exhibiting the controlled drug release for prolonged therapy. The patches were non-irritant to the skin, which led to improved efficacy and minimized the dosing frequency. Enhanced retention and permeation study stipulated superior potential application of these patches for the treatment of different skin injuries as compared to the marketed ointment [45].

\subsection{Liposomes and Liposomal Hydrogel}

Skin infection therapy is a challenging process due to the colonization of various bacteria, leading to the formation of biofilms which hinder the therapeutic efficacy of the formulation [77]. MUP is a golden drug for the treatment of various skin infections but is restricted to be used topically due to its in vivo inactivation and plasma protein 
binding [46]. Topical antimicrobials are the best alternative for the treatment of wound infections but possess certain limitations such as insufficient concentration and microbial resistance [49]. Therefore, to overcome such limitations, an ideal drug delivery system should contain the drug in sufficient concentration and release the antimicrobials in a sustained manner for a prolonged time, along with skin biocompatibility [50].

PEGylated liposomes have been identified as a potential carrier for the systemic and effective delivery of antimicrobials for the treatment of skin infection due to their biocompatibility, enhanced permeability (EP), immunogenicity, low toxicity, and amphiphilicity sustained and controlled release properties (Figure 5) $[46,49,78,79]$. Cern et al. developed MUP-loaded PEGylated nanoliposomes for the systemic delivery of MUP by providing metabolic protection and passive targeting to the infected area by the liposomal EP effect. The results revealed that HPCD enhances drug loading and inhibits the drug release in plasma. Nano-mupirocin (MUP-loaded PEGylated nanoliposomes comprising HPCD) was found stable [46]. Further, the therapeutic efficacy of the tailored nano-mupirocin was analyzed by intravenous administration in the mice necrotizing fasciitis model; no further disease signs and mortality were observed, in contrast to native MUP. Additionally, pharmacokinetic (PK) analysis was also carried out to assess the metabolic protection effect of the tailored formulation. Nano-mupirocin displayed magnified plasma concentration and was detectable for up to $24 \mathrm{~h}$, while native MUP showed rapid elimination and was detectable for up to $15 \mathrm{~min}$. After systemic administration, the area under the curve (AUC) of MUP was only $1 \%$ of the nano-mupirocin. The same trend was also observed in other PK parameters. The PK profile of the tailored formulation confirmed the passive targeting of MUP to the target infection under the EPR effect of the PEGylated nanoliposomes. A similar effect was observed in the (MRSA-induced) rabbit endocarditis model. In this study, MUP was administered intravenously the first time and portrayed a distinctive mechanism of action that resulted in a better treatment of resistant bacterial infection [47].

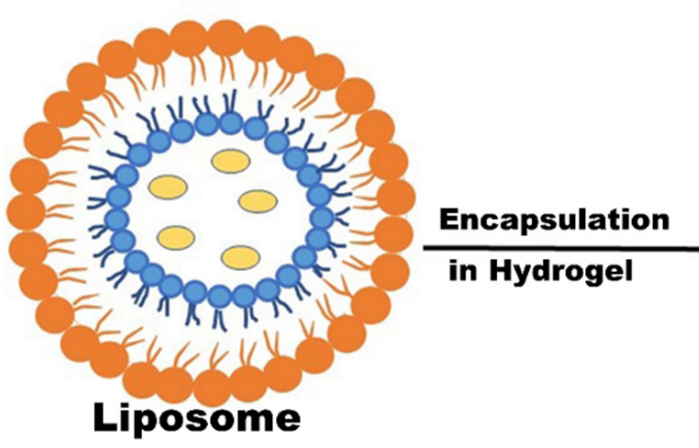

Therapeutic Moiety

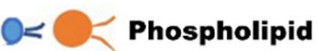

bilayer

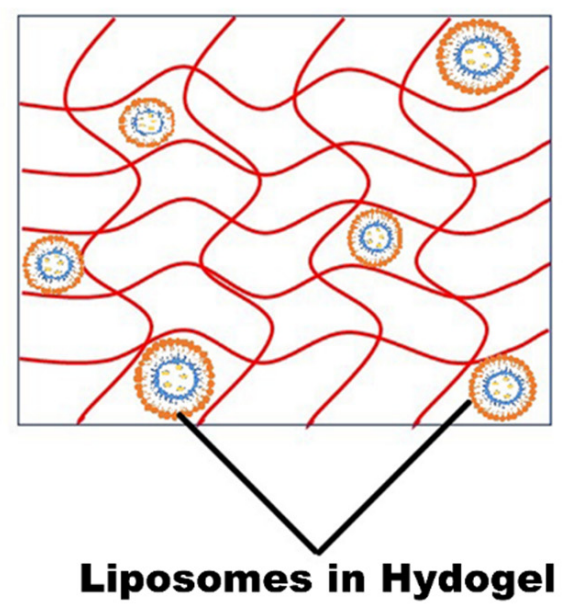

Figure 5. Therapeutic moiety-loaded biodegradable liposomes and liposomal hydrogel for biomedical application. The therapeutic moiety resides in the core of these liposomes.

In continuation of this, recently, the same group formulated MUP-loaded nanoliposomes $(74-85 \mathrm{~nm})$ for the systemic treatment of $S$. aureus infections. The bactericidal effect of the tailored formulation was significantly superior to the native MUP against S. aureus in the presence of plasma. The superior efficacy of the developed formulation was also evidenced by the significantly lower weight loss and reduced plasma concentration of inflammatory markers, such as Interleukin 6, in contrast to native MUP. The study demonstrated that nano-mupirocin was proficiently engulfed by phagocytosis via phagocytic cells, resulting in a magnified bactericidal property of MUP against $S$. aureus. In conclusion, the results stipulated that nano-mupirocin extended the topical application 
of MUP to the systemic application for the treatment of MRSA infections by changing the pharmacodynamics of MUP [48].

Liposomal hydrogels, a combination of liposomes and biocompatible polymeric hydrogels, are widely used in biomedical applications due to the improved formulation stabilities and dual property of liposomes and hydrogels (Figure 5) [80]. Hydrogel possesses durability, elasticity, biocompatibility, biodegradability, and adhesiveness [72]. Liposomes incorporated in the hydrogel delivery system exhibited satisfactory antimicrobial potential, making them suitable for improved wound therapy due to their sustained release property, along with bio-adhesives, leading to prolonged retention of the drug.

Hurler et al. developed liposomes containing MUP in chitosan hydrogel for the successful treatment of burn infections. Initially, MUP-loaded phosphatidylcholine liposomes were prepared by the conventional film method, and, later on, these liposomes were successfully incorporated into high-molecular-weight chitosan $(10 \%, w / w)$ hydrogel. Due to the sustained release potential of liposomes, the developed formulation showed a reduced frequency of administration in contrast to the MUP ( $2 \% w / w, 5-14$ days daily), leading to less stress and pain in the burn patients. Antimicrobial activity against $S$. aureus and $B$. subtilis revealed that the developed formulation was comparable to the marketed formulation [49]. Furthermore, the in vitro results revealed that the developed formulation was non-toxic to the $\mathrm{HaCaT}$ cells and possessed antibiofilm activity against $S$. aureus biofilms. The in vivo study results stipulated that the liposomes-MUP hydrogel intensifies wound healing and is equally potent to the marketed MUP formulation. However, a shorter healing time was observed in contrast to the marketed formulation [50].

\subsection{Microcapsule}

Microcapsules are designed for the sustained and controlled release of the therapeutic moiety to the target area. Microcapsules are micron-sized $(1-100 \mu \mathrm{m})$, spherical particles composed of natural/synthetic or semisynthetic polymers. Microparticles are widely utilized in different fields such as coating, composites, adhesives, cosmetics, and drug delivery applications [81]. In the drug delivery system, microparticles are categorized into various forms depending upon the location of the active pharmacophore.

A microcapsule-based drug delivery system was designed for the local delivery of MUP without unnecessary distribution to systemic circulation, leading to higher concentration to the skin for a prolonged time. The spray drying method was used for the formulation development by using Eudragit RS 100 polymer [51]. The same group developed and optimized other MUP-loaded microparticles by varying the different solvent concentrations (methanol, methanol:ethanol, 50:50 w/w), which significantly influenced the performance and stability of the formulation. Optimization results revealed that drug loading and solvent significantly influenced the morphology, in vitro drug release, and antimicrobial activity. Moreover, a drop of 4.8-5.0 and 4.8-4.9 $\mathrm{log} \mathrm{cfu} / \mathrm{mL}$ was observed for MRSA and ATCC 29213, respectively. Despite the high bactericidal concentrations employed, the time-kill assay was sensitive enough to detect differences between the drug and MP, providing strong evidence of the ability of the MP to prolong drug release. It is also important to note that any prospective usage of such microsystems in skin therapy requires adjustment of the initial dose of a once-a-day formulation. Moreover, a negligible impact was observed on the drug-loaded microparticle performance after 10 months of storage [52].

\subsection{Microsponges}

Microsponges have been commercially used for the topical delivery of various therapeutic agents due to their stability and efficient delivery of drugs at a comparatively minimal dose [82]. These drug delivery systems displayed magnified retention of therapeutic moiety on the skin surface due to minimal transdermal penetration of the drug. Microsponges are used for the treatment of various skin diseases including acne, skin 
infections, and diabetic wound healing due to their porosity, biocompatibility, and tailored drug release property.

Amrutiya et al. developed and optimized microsponges for the sustained and effective delivery of MUP against surgical wound infections. The developed microsponges were incorporated into an emulgel base, owning certain benefits of both emulsions and gels with uniquely fulfilling requirements of a carrier for topical drug delivery systems. Ex vivo drug disposition studies revealed $\sim 5$-fold retention on rat skin in contrast to MP ointment due to the occlusive effect. A Draize patch test evidenced that the optimized formulation was nonirritant to the skin. In vivo studies agreed that the optimized formulation was significantly safe and more therapeutically active in contrast to the marketed ointment. In conclusion, microsponge-based emulgels were a promising carrier for the effective treatment of primary and secondary skin infections due to biocompatibility, patient compliance, and magnified retention to the skin [53].

In another study, MUP was incorporated into a keratin $(\mathrm{K})$, fibrin $(\mathrm{F})$, and gelatin $(\mathrm{G})$ porous three-dimensional (3D) sponge (KFG-SPG-MP) for wound healing. The sponge was prepared by the freeze-drying technique. The developed formulation was highly porous with a fibril-like network that promotes oxygen transport, cell seeding, and imitates the function of the extracellular matrix, leading to magnified wound healing [83]. The developed formulation was biocompatible and stable due to the presence of KFG. A cell viability assay using $\mathrm{HaCaT}$ and NIH $3 \mathrm{~T} 3$ fibroblast cell lines stipulated that the 3D microsponge showed better cell viability in comparison to the control. Furthermore, the magnified therapeutic efficiency of the tailored formulation was witnessed by the antimicrobial study using the S. aureus and E. coli bacterial strain. In conclusion, the MUPloaded KFG sponge was a promising medicated dressing material for the treatment of wound infection [54].

\subsection{Nanoparticles/Naocapsules}

Nanoparticles/nanocapsules (NPs-1-100 nm) are colloidal particulate systems that have been widely used for the treatment of various skin diseases due to their low toxicity, shielding effect, and sustained and targeted drug delivery [84,85]. These vesicular systems are widely used for topical administration due to their stability and controlled release property [86]. To investigate the potential of NPs, MUP-loaded polymeric nanocapsules were prepared by nanoprecipitation method using two different oils, i.e., rosemary and caprylic/capric triglyceride. The nanoparticles manifested adequate particle size, monomodal size distributions, and low polydispersity index. All samples displayed a decrease in $\mathrm{pH}$ value after storing at $40^{\circ} \mathrm{C}$. Additionally, the formulations presented satisfactory zeta potential and an appropriate quantity of MUP loading. Further, the results demonstrated that the rosemary-oil-based formulation (NCMR) exhibited higher stability and therapeutic potential than caprylic/capric triglyceride (NCMT) [55].

Recently, a novel selenium-chitosan-MUP nanohybrid formulation (M-SeNPs-CCH) was fabricated to overcome MRSA resistance. The nanohybrid system was fabricated using MUP (M) and selenium nanoparticles (SeNPs) embedded in a chitosan-cetyltrimethylammonium bromide $(\mathrm{CTAB})$ hydrogel $(\mathrm{CCH})$. The antimicrobial susceptibility results demonstrated that M-SeNPs-CCH exhibited a threefold reduction in MIC. The disc diffusion results revealed a magnified zone of inhibition of M-SeNPs-CCH, M-SeNPs, and M-CCH (24, 22 , and $23 \mathrm{~mm}$, respectively) in contrast to MUP $(19 \mathrm{~mm})$, corroborating the enhanced antibacterial potential. The wound healing results revealed that M-SeNPs-CCH showed remarkable therapeutic potential in terms of wound healing and wound contraction compared to the native MUP. Furthermore, the histopathological analysis results stipulated enhanced collagenization and epimerization in all three groups of M-SeNPs, M-CCH, and M-SeNPs-CCH for 21 days. In conclusion, the developed hybrid system was more effective than the bare MUP owing to the substantial property of CCH and SeNPs (Figure 6) [56]. 

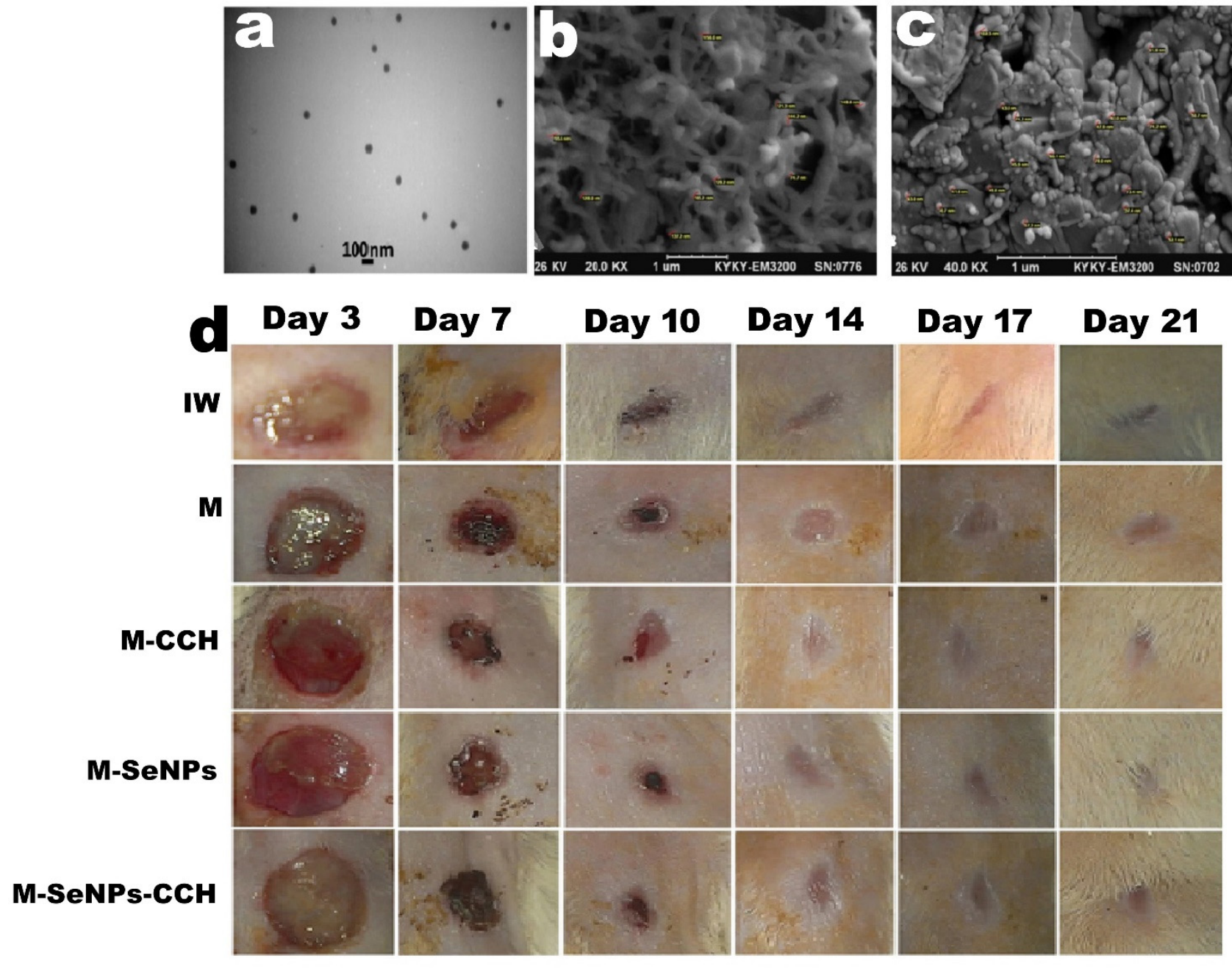

Figure 6. Selenium-chitosan-mupirocin (M) nanohybrid system for wound healing (a) scanning electron microscopy image (SEM) of selenium nanoparticles (SeNPs); (b) SEM image of chitosan-N-cetyl-N, N, N-trimethylammonium bromide-based hydrogel $(\mathrm{CCH})$; (c) SeNPs-loaded $\mathrm{CCH}$; (d) the histopathological images of wound healing of untreated (infectious wound; IW) and treated groups (M, M-CCH, M-SeNPs, M-SeNPs-CCH) on days 3, 7, 10, 14, 17, and 21. The results were obtained based on triple independent tests $(p \leq 0.05)$ Reproduced from [56], Nature, 2020.

A novel formulation MUP-NPs-loaded hydrogel (MLH) was designed to treat wound healing. MLH comprises thermosensitive amphiphilic poly (ethylene oxide)-poly (propylene oxide)-poly (ethylene oxide) (PEO-PPO-PEO) block copolymers (P407, poloxamer) NPs in PVA. The tailored formulation was synthesized by a two-step procedure, initially by synthesis of MUP-loaded gelatin/carbopol 934 nanoparticles by spray drying method and then followed by loading to these nanoparticles into the poloxamer hydrogel. In contrast to MUP, MLH exhibited a progressive controlled drug release ointment due to the cubic phase behavior of thermosensitive polymer and PVA hydrogel. The MLH exhibited reduced MIC and minimum bactericidal concentrations against S. aureus, S. epidermidis, Pseudomonas aeruginosa, and E. coli compared to the MUP ointment [57]. Recently, the same group studied the biocompatibility and safety of MLH for wound healing in the rat model. The cytocompatibility results revealed that the formulation was non-toxic to human fibroblast cells and human epidermal keratinocytes. Moreover, MLH exhibited improved wound healing, reduced necrosis, and lower inflammation in contrast to MUP [58].

\subsection{Nanofibers}

Nanofibers are excellent, three-dimensional, bioengineered therapeutic materials for the treatment of acute and chronic wounds and burns. These are mainly used as dress- 
ing material due to their structural and functional resemblance to the fibrillar structure of the native extracellular matrix (ECM), wound healing stimulation, biocompatibility, biodegradability leading to support cell adhesion, proliferation, and differentiation [62,87]. Nanofibers also protect the wound from external environmental contamination and adsorb the wound exudates, and their porous nature permeates oxygen, moisture, and eliminates the metabolic waste $[88,89]$. Further, these possess superior loading capacity (antibiotics, genes, herbal medicines, growth factors) due to their enormous surface area, leading to increased homeostasis and tissue growth (Figure 7). Moreover, high surface area boosts the absorption of various active proteins such as fibronectin, albumin, and laminin. Additionally, traumas can be avoided during the detachment of dressings owing to their controlled biodegradation $[62,88,90]$. Various techniques are used for the fabrication of nanofibers, but, currently, the electrospinning technique is preferable, owing to its cost-effectiveness and the facile fabrication of nanofibers with a size range of 5-100 $\mathrm{nm}$ from the natural and synthetic polymer in contrast to other techniques $[87,89]$. Thakur et al. fabricated an electrospun polymeric (poly-l-lactic acid) nanofiber scaffold comprising MUP and lidocaine hydrochloride (LH) as a wound dressing material. The tailored scaffold exhibited a different release profile for both drugs. Initially, LH exhibited burst release (80\% up to $1 \mathrm{~h}$ ), and, later on, sustained release was observed, whereas MUP exhibited only $5 \%$ release initially $(1 \mathrm{~h})$, followed by sustained release for up to $72 \mathrm{~h}$, leading to maintaining the antibacterial effect. The in vitro drug release results suggest that the release kinetics of one drug was altered by keeping the two different drugs in the same polymer matrix. The dual drug scaffold released a significantly higher drug than the MIC and even compensated the inactive monic acid to act on the applied area, resulting in maintaining a sufficient concentration of MUP in the infected wound for more than a $72 \mathrm{~h}$ period. Further, the cell viability results evidenced the biocompatibility of the tailored formulation. The results revealed that both drugs did not show any significant inhibitory effect on cell proliferation together with profound wound healing [59]. In a study, electrospun polyurethane (PU) nanofibers comprising MUP (PU/MUP) were developed as burn wound dressing for the prevention of wound infection. The developed fiber mat was enough for wound hydration via providing adequate ambient humidity. Moreover, the PU/MUP nanofiber exhibited sufficient cell spreading and attachment. Furthermore, the therapeutic efficiency of PU/MUP-nanofiber-based dressing material was assessed by the antibacterial activity against $S$. aureus. The results revealed that the antibacterial activity of the scaffold was increased proportionally with the increase in MUP concentration (2-5\%). However, the formulation was not effective against $P$. aeruginosa and E. coli, suggesting a lower probability of cross-resistance. The histopathological study revealed that the PU/MUP nanofibrous mat was enough for burn wound healing due to negligible inflammation. In conclusion, these MUP-loaded PU nanofibers were potential candidates for the management of early burn injury infection together with magnified wound healing [60].

Li et al. fabricated a multifunctional double-layer nanofibrous scaffold (MDLS) for the management of wound infection. The first layer that is exposed to the environment comprises MUP and polycaprolactone (PCL), imparting an antibacterial effect. The second layer, in direct contact with the infection, was composed of chitosan nanofibers impregnated with lidocaine (Lid) as a pain reliever. Further, the antibacterial effect also supported the sustained release pattern of MUP via showing more effectiveness of MDLS against $S$. aureus, P. aeruginosa, and E. coli. Additionally, cytotoxicity results revealed that the MDLS was more biocompatible due to the addition of chitosan in contrast to PCL nanofibers [61]. Recently, MUP (2\%), keratin $(0.01-0.1 \% w / w)$, and coenzyme Q10-loaded $(0.05-0.15 \% w / w)$ polyvinyl alcohol (PVA, $10 \% w / v)$ electrospun nanofibers were fabricated for the treatment of wound infection. The diameter of all fabricated nanofibers was $2.11 \pm 0.20$ to $3.27 \pm 0.10 \mathrm{~nm}$. The in vitro results showed a biphasic release pattern: initial burst release followed by sustained release for up to $2 \mathrm{~h}$. All the formulations were biocompatible, evidenced by the skin irritancy test. Further, the therapeutic efficacy of the tailored formulation was assessed by antimicrobial activity against various strains of $S$. aureus $(2583,2586,2587$, 
2590), MRSA 2555, and E. coli 1808. The results revealed that all the formulations exhibited magnified activity against $S$. aureus, hence were more effective for the treatment of wound infection. Moreover, cell proliferation results evidenced the ability of nanofibers to support the keratinocytes' growth due to the presence of coenzyme Q10. In conclusion, the tailored formulations have the potential as a wound dressing material due to the antibacterial property of MUP, PVA biocompatibility, bioactive nature of coenzyme Q10, and keratin [62].

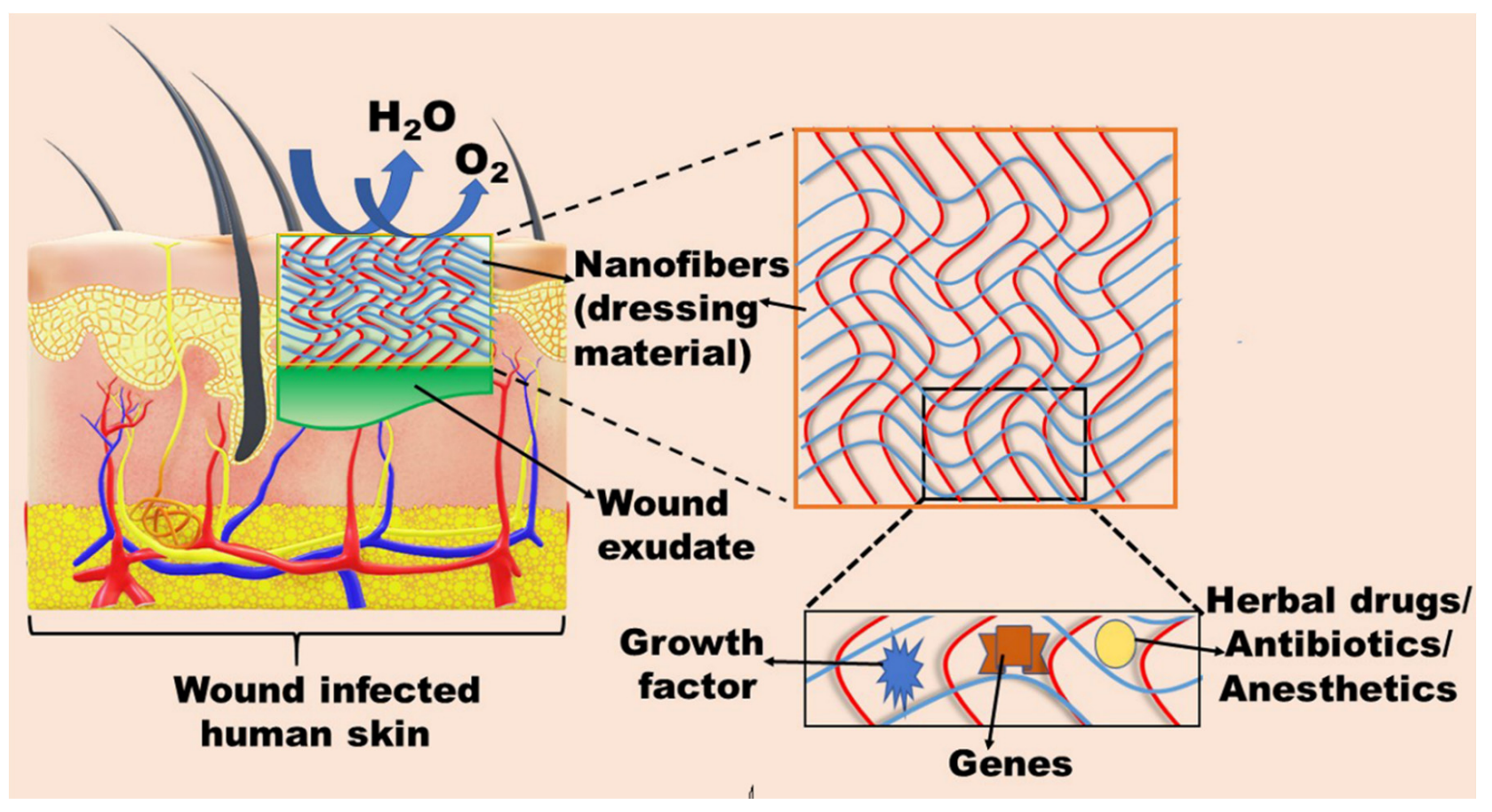

Figure 7. Nanofibers-based dressing material for the treatment of wound infection.

\subsection{Miscellaneous}

The topical spray has been identified as a versatile formulation for the treatment of skin infection due to thin film formation on the wound infections. Film flexibility permits adaptation to body contours and its mechanical properties may be increased by repeated spraying to build up several overlapping layers. Regarding this, Sritharadol et al. developed MUP-loaded topical spray by using a film-forming agent (Eudragit E100) for wound healing and bacterial skin infection treatment. The developed formulation exhibited superior physical and chemical stability for up to one year, along with $80 \%$ of the drug content. The optimized formulation and marketed ointment (Bactroban) exhibited almost similar antimicrobial activity against $S$. aureus and S. epidermidis. However, the spray exhibited magnified antimicrobial activity (18-fold) against $S$. suis, in contrast to the marketed formulation. This significant difference was due to the close contact of spray and skin, leading to the formation of a thin film on the infected surface. Moreover, the topical formulation was found non-irritant to the human skin without any toxicity to the monocytes, keratinocytes, and fibroblasts cells. Additionally, the safety profile of the formulation was also confirmed by zero production of nitric oxide and inflammatory cytokines (IL-1b and TNF-a) due to its antiendotoxin effect [63]. In another study, the same group assessed the antibiofilm property of the developed formulation against $E$. coliinduced infections. The results revealed that topical spray prevented the biofilm formation together with disruption and removal of the preformed biofilm, leading to enhancing the MUP antibiofilm property [18].

A nanostructured lipid carrier (NLC) is another promising cargo for the enhanced delivery of MUP due to higher loading, prolonged release, improved bioavailability, and long-term storage stability [64]. NLCs are a blend of solid and liquid lipids in which 
the oil core is uniformly assimilated into the solid-liquid lipid core, leading to higher drug loading and controlled release [91]. The lipid matrix of NLCs acts as a physical barrier, which may protect the encapsulated sensitive active compound from damaging factors in the aqueous phase. MUP-loaded NLCs (MNLCs) were prepared by using solidlipid (cetyl palmitate) and liquid-lipid (caprylic/caprylic acid) in 5 different ratios and further characterized for i.v administration. All the formulations displayed mean particle size in the range of $99.8-235 \mathrm{~nm}$. It was observed that the encapsulation efficiency was significantly influenced by the varying ratio of solid and liquid-lipid. In vitro release results revealed that the drug release was remarkably influenced by the particle size. The smallest size MNLC released $94.51 \%$ drug within $7 \mathrm{~h}$ together with magnified storage stability. The selected formulation was safe at a $250 \mathrm{mg} / \mathrm{kg}$ dose in rats, with no signs of appetite loss, mortality, and hypersensitivity. Additionally, the MIC value of MNLC1 was $1.56 \mu \mathrm{g} / \mathrm{mL}$ and $0.78 \mu \mathrm{g} / \mathrm{mL}$, while the MIC value of MUP was $6.25 \mu \mathrm{g} / \mathrm{mL}$ and $1.56 \mu \mathrm{g} / \mathrm{mL}$ MIC against S. pyogenes and S. aureus, respectively. Moreover, the protective effect of NLCs was confirmed by pharmacokinetic analysis. The results revealed that the metabolic degradation of MUP was hampered by the protective lipid layer of NLCS, resulting in a 40-fold and 55-fold area under the curve and half-life, respectively, in contrast to native MUP [64].

Further, the therapeutic efficacy of MUP can also be enhanced by combining MUP with other therapeutic modalities, such as sucralfate, and various monoterpenes. It was found that the antibacterial efficacy of MUP was enhanced by combing with topical sucralfate in contrast to MUP alone. The results revealed that the skin ulcer area was reduced significantly in the combination treatment [92]. In another study, antimicrobial activity against $S$. aureus, MUP alone, or both in combination with any of monoterpenes, such as thymol, menthol, and 1,8-cineole, was tested. MUP-1,8 cineole, MUP-menthol exhibited a strong biofilm-eliminating effect and antagonism respectively, while the MUP-thymol mixture was indecisive [93]. Recently, Jagdale et al. developed MUP-loaded emulgel for the treatment of skin infection. The developed gel was stable and MUP was released in a controlled manner together with superior antimicrobial property [94].

\section{Conclusions}

Mupirocin is a globally used topical antibiotic for the treatment of various bacterial skin infections owing to its unique mechanism of action; however, the therapeutic efficacy is hampered due to resistance, poor half-life, and protein binding. The therapeutic efficacy of MUP can be augmented by combining with other agents and using a suitable biocompatible carrier that promotes and support cell viability and cell proliferation together with sustained release of MUP. The sustained and progressive release of MUP from the novel carrier can maintain the drug concentration in the therapeutic window without adverse effects and resistance. Moreover, dual drug strategies/multifunctional nanofibers also play an important role in the prevention of biodegradation of MUP via altering the drug release kinetics. All the carriers/dressing materials are biocompatible, biodegradable, stimulate wound healing, protect the wound from external environmental contamination, adsorb the wound exudates, and are permeable to oxygen and moisture. Further, the resistance can be overcome by the controlled use of MUP for the target decolonization, and, when used as a prophylactic, can limit the treatment duration by up to 10 days, and means there is no need to repeat the treatment for up to 30 days.

Author Contributions: Conceptulization, writing—original draft preparation P.K. (Preeti Kush) and A.G.; writing-review and editing, P.K. (Parveen Kumar) and R.S. All authors have read and agreed to the published version of the manuscript.

Funding: Not applicable.

Institutional Review Board Statement: Not applicable.

Informed Consent Statement: Not Applicable. 


\section{Data Availability Statement: Not Applicable.}

Acknowledgments: Preeti Kush and Ranjit Singh thanks to Shobhit University, Gangoh, Saharanpur, Uttar Pradesh 247341 Saharanpur, U.P.

Conflicts of Interest: The authors declare that they have no conflict of interest.

\section{References}

1. Ibrahim, F.; Khan, T.; Pujalte, G.G. Bacterial Skin Infections. Prim. Care 2015, 42, 485-499. [CrossRef]

2. Kaye, K.S.; Petty, L.A.; Shorr, A.F.; Zilberberg, M.D. Current Epidemiology, Etiology, and Burden of Acute Skin Infections in the United States. Clin. Infect. Dis. 2019, 68, S193-S199. [CrossRef]

3. Kollipara, R.; Downing, C.; Lee, M.; Guidry, J.; Curtis, S.; Tyring, S. Current and emerging drugs for acute bacterial skin and skin structure infections: An update. Expert Opin. Emerg. Drugs 2014, 19, 431-440. [CrossRef] [PubMed]

4. Mistry, R.D. Skin and Soft Tissue Infections in Ambulatory Care Settings: Setting a New Trend. J. Clin. Infect. Dis. 2019, 70, 2719-2720. [CrossRef] [PubMed]

5. $\quad$ Edelsberg, J.; Taneja, C.; Zervos, M.; Haque, N.; Moore, C.; Reyes, K.; Spalding, J.; Jiang, J.; Oster, G. Trends in US hospital admissions for skin and soft tissue infections. Emerg. Infect. Dis. 2009, 15, 1516-1518. [CrossRef] [PubMed]

6. Esposito, S.; Ascione, T.; Pagliano, P. Management of bacterial skin and skin structure infections with polymicrobial etiology. Expert Rev. Anti-Infect. Ther. 2019, 17, 17-25. [CrossRef]

7. Sukumaran, V.; Senanayake, S. Bacterial skin and soft tissue infections. Aust. Prescr. 2016, 39, 159-163. [CrossRef]

8. Esposito, S.; Noviello, S.; Leone, S. Epidemiology and microbiology of skin and soft tissue infections. Curr. Opin. Infect. Dis. 2016, 29, 109-115. [CrossRef]

9. Breyre, A.; Frazee, B.W. Skin and Soft Tissue Infections in the Emergency Department. Emerg. Med. Clin. N. Am. 2018, 36, 723-750. [CrossRef]

10. Russo, A.; Concia, E.; Cristini, F.; De Rosa, F.G.; Esposito, S.; Menichetti, F.; Petrosillo, N.; Tumbarello, M.; Venditti, M.; Viale, P.; et al. Current and future trends in antibiotic therapy of acute bacterial skin and skin-structure infections. Clin. Microbiol. Infect. 2016, 22 (Suppl. 2), S27-S36. [CrossRef]

11. Lipsky, B.A.; Silverman, M.H.; Joseph, W.S. A Proposed New Classification of Skin and Soft Tissue Infections Modeled on the Subset of Diabetic Foot Infection. Open Forum. Infect. Dis. 2017, 4, ofw255. [CrossRef]

12. Stevens, D.L.; Bisno, A.L.; Chambers, H.F.; Dellinger, E.P.; Goldstein, E.J.; Gorbach, S.L.; Hirschmann, J.V.; Kaplan, S.L.; Montoya, J.G.; Wade, J.C. Practice guidelines for the diagnosis and management of skin and soft tissue infections: 2014 update by the Infectious Diseases Society of America. Clin. Infect. Dis. 2014, 59, 147-159. [CrossRef]

13. Ni Riain, U. Recommended management of common bacterial skin infections. Prescriber 2011, 22, 14-24. [CrossRef]

14. Clebak, K.T.; Malone, M.A. Skin Infections. Prim. Care 2018, 45, 433-454. [CrossRef]

15. Bergstein, J.M.; Baker, E.J.t.; Aprahamian, C.; Schein, M.; Wittmann, D.H. Soft tissue abscesses associated with parenteral drug abuse: Presentation, microbiology, and treatment. Am. Surg. 1995, 61, 1105-1108.

16. Talan, D.A.; Summanen, P.H.; Finegold, S.M. Ampicillin/sulbactam and cefoxitin in the treatment of cutaneous and other soft-tissue abscesses in patients with or without histories of injection drug abuse. Clin. Infect. Dis. 2000, 31, 464-471. [CrossRef] [PubMed]

17. Norbury, W.; Herndon, D.N.; Tanksley, J.; Jeschke, M.G.; Finnerty, C.C. Infection in Burns. Surg. Infect. 2016, 17, 250-255. [CrossRef] [PubMed]

18. Bakkiyaraj, D.; Sritharadol, R.; Padmavathi, A.R.; Nakpheng, T.; Srichana, T. Anti-biofilm properties of a mupirocin spray formulation against Escherichia coli wound infections. Biofouling 2017, 33, 591-600. [CrossRef] [PubMed]

19. Fung, H.B.; Chang, J.Y.; Kuczynski, S. A practical guide to the treatment of complicated skin and soft tissue infections. Drugs 2003, 63, 1459-1480. [CrossRef]

20. Macdonald, K.E.; Jordan, C.Y.; Crichton, E.; Barnes, J.E.; Harkin, G.E.; Hall, L.M.L.; Jones, J.D. A retrospective analysis of the microbiology of diabetic foot infections at a Scottish tertiary hospital. BMC Infect. Dis. 2020, 20, 218. [CrossRef]

21. Goldstein, E.J.; Citron, D.M.; Merriam, C.V.; Tyrrell, K.; Warren, Y. Activity of gatifloxacin compared to those of five other quinolones versus aerobic and anaerobic isolates from skin and soft tissue samples of human and animal bite wound infections. Antimicrob. Agents Chemother. 1999, 43, 1475-1479. [CrossRef] [PubMed]

22. Gentry, L.O. Review of quinolones in the treatment of infections of the skin and skin structure. J. Antimicrob. Chemother. 1991, 28 (Suppl. C), 97-110. [CrossRef]

23. Williamson, D.A.; Carter, G.P.; Howden, B.P. Current and Emerging Topical Antibacterials and Antiseptics: Agents, Action, and Resistance Patterns. Clin. Microbiol. Rev. 2017, 30, 827-860. [CrossRef] [PubMed]

24. Tucaliuc, A.; Blaga, A.C.; Galaction, A.I.; Cascaval, D. Mupirocin: Applications and production. Biotechnol. Lett. 2019, 41, 495-502. [CrossRef]

25. Rakshit, T.; Shenoy, M.S. How resistant is Staphylococcus aureus to the topical antibiotic mupirocin? J. Glob. Antimicrob. Resist. 2017, 8, 102-103. [CrossRef]

26. Ha, K.R.; Psaltis, A.J.; Butcher, A.R.; Wormald, P.-J.; Tan, L.W. In Vitro Activity of Mupirocin on Clinical Isolates of Staphylococcus aureus and its Potential Implications in Chronic Rhinosinusitis. Laryngoscope 2008, 118, 535-540. [CrossRef] 
27. Cern, A.; Connolly, K.L.; Jerse, A.E.; Barenholz, Y. In Vitro Susceptibility of Neisseria gonorrhoeae Strains to Mupirocin, an Antibiotic Reformulated for Parenteral Administration in Nanoliposomes. Antimicrob. Agents Chemother. 2018, 62. [CrossRef]

28. O'Donnell, J.A.; Gelone, S.P.; Safdar, A. 37-Topical Antibacterials. In Mandell, Douglas, and Bennett's Principles and Practice of Infectious Diseases, 8th ed.; Bennett, J.E., Dolin, R., Blaser, M.J., Eds.; W.B. Saunders: Philadelphia, PA, USA, $2015 ;$ pp. 452-462.e452.

29. Breneman, D.L. Use of mupirocin ointment in the treatment of secondarily infected dermatoses. J. Am. Acad. Dermatol. 1990, 22, 886-892. [CrossRef]

30. David, S.R.; Malek, N.; Mahadi, A.H.; Chakravarthi, S.; Rajabalaya, R. Development of controlled release silicone adhesive-based mupirocin patch demonstrates antibacterial activity on live rat skin against Staphylococcus aureus. Drug. Des. Devel. Ther. 2018, 12, 481-494. [CrossRef]

31. Tacconelli, E.; Foschi, F.; Forstner, C.; Finch, R.G.; Pletz, M.W. 136-Principles of Anti-infective Therapy and Surgical Prophylaxis. In Infectious Diseases, 4th ed.; Cohen, J., Powderly, W.G., Opal, S.M., Eds.; Elsevier: Amsterdam, The Netherlands, 2017; pp. 1145-1161.e1142.

32. Khoshnood, S.; Heidary, M.; Asadi, A.; Soleimani, S.; Motahar, M.; Savari, M.; Saki, M.; Abdi, M. A review on mechanism of action, resistance, synergism, and clinical implications of mupirocin against Staphylococcus aureus. Biomed. Pharmacother. 2019, 109, 1809-1818. [CrossRef] [PubMed]

33. Gurney, R.; Thomas, C.M. Mupirocin: Biosynthesis, special features and applications of an antibiotic from a gram-negative bacterium. Appl. Microbiol. Biotechnol. 2011, 90, 11-21. [CrossRef]

34. Greywal, T.; Cohen, P.R. Erythrasma: A report of nine men successfully managed with mupirocin $2 \%$ ointment monotherapy. Dermatol. Online J. 2017, 23. [CrossRef]

35. Bari, O.; Cohen, P.R. Successful Management of Zoon's Balanitis with Topical Mupirocin Ointment: A Case Report and Literature Review of Mupirocin-Responsive Balanitis Circumscripta Plasmacelluaris. Dermatol. Ther. (Heidelb.) 2017, 7, 203-210. [CrossRef]

36. van Bambeke, F.; Mingeot-Leclercq, M.-P.; Glupczynski, Y.; Tulkens, P.M. 137-Mechanisms of Action. In Infectious Diseases, 4th ed.; Cohen, J., Powderly, W.G., Opal, S.M., Eds.; Elsevier: Amsterdam, The Netherlands, 2017; pp. 1162-1180.e1161.

37. Thomas, C.M.; Hothersall, J.; Willis, C.L.; Simpson, T.J. Resistance to and synthesis of the antibiotic mupirocin. Nat. Rev. Microbiol. 2010, 8, 281-289. [CrossRef]

38. Poovelikunnel, T.; Gethin, G.; Humphreys, H. Mupirocin resistance: Clinical implications and potential alternatives for the eradication of MRSA. J. Antimicrob. Chemother. 2015, 70, 2681-2692. [CrossRef] [PubMed]

39. Ramadass, S.K.; Perumal, S.; Gopinath, A.; Nisal, A.; Subramanian, S.; Madhan, B. Sol-gel assisted fabrication of collagen hydrolysate composite scaffold: A novel therapeutic alternative to the traditional collagen scaffold. ACS Appl. Mater. Interfaces 2014, 6, 15015-15025. [CrossRef]

40. Perumal, S.; Ramadass, S.; Madhan, B. Sol-gel processed mupirocin silica microspheres loaded collagen scaffold: A synergistic bio-composite for wound healing. Eur. J. Pharm. Sci. 2014, 52, 26-33. [CrossRef] [PubMed]

41. Üstündă̆ Okur, N.; Hökenek, N.; Okur, M.E.; Ayla, Ş.; Yoltaş, A.; Siafaka, P.I.; Cevher, E. An alternative approach to wound healing field; new composite films from natural polymers for mupirocin dermal delivery. Saudi Pharm. J. 2019, 27, 738-752. [CrossRef]

42. Zhao, H.; Huang, J.; Li, Y.; Lv, X.; Zhou, H.; Wang, H.; Xu, Y.; Wang, C.; Wang, J.; Liu, Z. ROS-scavenging hydrogel to promote healing of bacteria infected diabetic wounds. Biomaterials 2020, 258, 120286. [CrossRef]

43. Ahmad, S.; Minhas, M.U.; Ahmad, M.; Sohail, M.; Abdullah, O.; Badshah, S.F. Preparation and Evaluation of Skin Wound Healing Chitosan-Based Hydrogel Membranes. AAPS PharmSciTech 2018, 19, 3199-3209. [CrossRef]

44. Ahmad, S.; Minhas, M.U.; Ahmad, M.; Sohail, M.; Khalid, Q.; Abdullah, O. Synthesis and evaluation of topical hydrogel membranes; a novel approach to treat skin disorders. J. Mater. Sci. Mater. Med. 2018, 29, 191. [CrossRef]

45. Ahmad, S.; Usman Minhas, M.; Ahmad, M.; Sohail, M.; Abdullah, O.; Khan, K.U. Topical hydrogel patches of vinyl monomers containing mupirocin for skin injuries: Synthesis and evaluation. Adv. Polym. Technol. 2018, 37, 3401-3411. [CrossRef]

46. Cern, A.; Nativ-Roth, E.; Goldblum, A.; Barenholz, Y. Effect of solubilizing agents on mupirocin loading into and release from PEGylated nanoliposomes. J. Pharm. Sci. 2014, 103, 2131-2138. [CrossRef] [PubMed]

47. Cern, A.; Michael-Gayego, A.; Bavli, Y.; Koren, E.; Goldblum, A.; Moses, A.E.; Xiong, Y.Q.; Barenholz, Y. Nano-mupirocin: Enabling the parenteral activity of mupirocin. J. Eur. J. Nanomed. 2016, 8, 139. [CrossRef]

48. Goldmann, O.; Cern, A.; Müsken, M.; Rohde, M.; Weiss, W.; Barenholz, Y.; Medina, E. Liposomal mupirocin holds promise for systemic treatment of invasive Staphylococcus aureus infections. J. Control. Release 2019, 316, 292-301. [CrossRef] [PubMed]

49. Hurler, J.; Berg, O.A.; Skar, M.; Conradi, A.H.; Johnsen, P.J.; Skalko-Basnet, N. Improved burns therapy: Liposomes-in-hydrogel delivery system for mupirocin. J. Pharm. Sci. 2012, 101, 3906-3915. [CrossRef] [PubMed]

50. Hurler, J.; Sørensen, K.K.; Fallarero, A.; Vuorela, P.; Škalko-Basnet, N. Liposomes-in-Hydrogel Delivery System with Mupirocin:In Vitro Antibiofilm Studies and In Vivo Evaluation in Mice Burn Model. BioMed. Res. Int. 2013, 2013, 498485. [CrossRef]

51. Dürrigl, M.; Kwokal, A.; Hafner, A.; Segvić Klarić, M.; Dumičić, A.; Cetina-Čižmek, B.; Filipović-Grčić, J. Spray dried microparticles for controlled delivery of mupirocin calcium: Process-tailored modulation of drug release. J. Microencapsul. 2011, 28 , 108-121. [CrossRef]

52. Dürrigl, M.; Kregar, M.L.; Hafner, A.; Klarić, M.; Filipović-Grčić, J. Mupirocin calcium microencapsulation via spray drying: Feed solvent influence on microparticle properties, stability and antimicrobial activity. Drug Dev. Ind. Pharm. 2011, 37, 1402-1414. [CrossRef] [PubMed] 
53. Amrutiya, N.; Bajaj, A.; Madan, M. Development of microsponges for topical delivery of mupirocin. AAPS PharmSciTech 2009, 10, 402-409. [CrossRef]

54. Singaravelu, S.; Ramanathan, G.; Raja, M.D.; Nagiah, N.; Padmapriya, P.; Kaveri, K.; Sivagnanam, U.T. Biomimetic interconnected porous keratin-fibrin-gelatin 3D sponge for tissue engineering application. Int. J. Biol. Macromol. 2016, 86, 810-819. [CrossRef]

55. Rubenick, J.B.; Rubim, A.M.; Bellé, F.; Nogueira-Librelotto, D.R.; Rolim, C.M.B. Preparation of mupirocin-loaded polymeric nanocapsules using essential oil of rosemary. J Braz. J. Pharm. Sci. 2017, 53. [CrossRef]

56. Golmohammadi, R.; Najar-Peerayeh, S.; Tohidi Moghadam, T.; Hosseini, S.M.J. Synergistic Antibacterial Activity and Wound Healing Properties of Selenium-Chitosan-Mupirocin Nanohybrid System: An in Vivo Study on Rat Diabetic Staphylococcus aureus Wound Infection Model. Sci. Rep. 2020, 10, 2854. [CrossRef]

57. Kamlungmak, S.; Rugmai, S.; Tinpun, K.; Nakpheng, T.; Srichana, T. Phase behavior, in vitro drug release, and antibacterial activity of thermoresponsive poloxamer-polyvinyl alcohol hydrogel-loaded mupirocin nanoparticles. Appl. Polym. 2020, 137, 49325. [CrossRef]

58. Kamlungmak, S.; Nakpheng, T.; Kaewpaiboon, S.; Mudhar Bintang, M.A.K.; Prom-in, S.; Chunhachaichana, C.; Suwandecha, T.; Srichana, T. Safety and Biocompatibility of Mupirocin Nanoparticle-Loaded Hydrogel on Burn Wound in Rat Model. Biol. Pharm. Bull. 2021, 44, 1707-1716. [CrossRef]

59. Thakur, R.A.; Florek, C.A.; Kohn, J.; Michniak, B.B. Electrospun nanofibrous polymeric scaffold with targeted drug release profiles for potential application as wound dressing. Int. J. Pharm. 2008, 364, 87-93. [CrossRef]

60. Chen, X.; Zhao, R.; Wang, X.; Li, X.; Peng, F.; Jin, Z.; Gao, X.; Yu, J.; Wang, C. Electrospun mupirocin loaded polyurethane fiber mats for anti-infection burn wound dressing application. J. Biomater. Sci. Polym. Ed. 2017, 28, 162-176. [CrossRef] [PubMed]

61. Li, X.; Wang, C.; Yang, S.; Liu, P.; Zhang, B. Electrospun PCL/mupirocin and chitosan/lidocaine hydrochloride multifunctional double layer nanofibrous scaffolds for wound dressing applications. Int. J. Nanomed. 2018, 13, 5287-5299. [CrossRef]

62. Amajuoyi, J.N.; Ilomuanya, M.O.; Asantewaa-Osei, Y.; Azubuike, C.P.; Adeosun, S.O.; Igwilo, C.I. Development of electrospun keratin/coenzyme Q10/poly vinyl alcohol nanofibrous scaffold containing mupirocin as potential dressing for infected wounds. Future J. Pharm. Sci. 2020, 6, 25. [CrossRef]

63. Sritharadol, R.; Nakpheng, T.; Wan Sia Heng, P.; Srichana, T. Development of a topical mupirocin spray for antibacterial and wound-healing applications. Drug Dev. Ind. Pharm. 2017, 43, 1715-1728. [CrossRef]

64. Alcantara, K.P.; Zulfakar, M.H.; Castillo, A.L. Development, characterization and pharmacokinetics of mupirocin-loaded nanostructured lipid carriers (NLCs) for intravascular administration. Int. J. Pharm. 2019, 571, 118705. [CrossRef] [PubMed]

65. Salernitano, E.; Migliaresi, C. Composite Materials for Biomedical Applications: A Review. J. Appl. Biomater. Funct. Mater. 2003, 1, 3-18. [CrossRef]

66. Serpooshan, V.; Zhao, M.; Metzler, S.A.; Wei, K.; Shah, P.B.; Wang, A.; Mahmoudi, M.; Malkovskiy, A.V.; Rajadas, J.; Butte, M.J.; et al. The effect of bioengineered acellular collagen patch on cardiac remodeling and ventricular function post myocardial infarction. Biomaterials 2013, 34, 9048-9055. [CrossRef]

67. Lin, J.; Li, C.; Zhao, Y.; Hu, J.; Zhang, L.-M. Co-electrospun Nanofibrous Membranes of Collagen and Zein for Wound Healing. ACS Appl. Mater. Interfaces 2012, 4, 1050-1057. [CrossRef] [PubMed]

68. Ficai, A.; Albu, M.G.; Birsan, M.; Sonmez, M.; Ficai, D.; Trandafir, V.; Andronescu, E. Collagen hydrolysate based collagen/hydroxyapatite composite materials. J. Mol. Struct. 2013, 1037, 154-159. [CrossRef]

69. Ma, L.; Gao, C.; Mao, Z.; Zhou, J.; Shen, J.; Hu, X.; Han, C. Collagen/chitosan porous scaffolds with improved biostability for skin tissue engineering. Biomaterials 2003, 24, 4833-4841. [CrossRef]

70. Zahedi, P.; Rezaeian, I.; Ranaei-Siadat, S.-O.; Jafari, S.-H.; Supaphol, P. A review on wound dressings with an emphasis on electrospun nanofibrous polymeric bandages. Polym. Adv. Technol. 2010, 21, 77-95. [CrossRef]

71. Li, S.; Dong, S.; Xu, W.; Tu, S.; Yan, L.; Zhao, C.; Ding, J.; Chen, X. Antibacterial Hydrogels. Adv. Sci. 2018, 5, 1700527. [CrossRef] [PubMed]

72. Yazdi, M.K.; Vatanpour, V.; Taghizadeh, A.; Taghizadeh, M.; Ganjali, M.R.; Munir, M.T.; Habibzadeh, S.; Saeb, M.R.; Ghaedi, M. Hydrogel membranes: A review. Mater. Sci. Eng. C 2020, 114, 111023. [CrossRef]

73. Mohamad, N.; Mohd Amin, M.C.; Pandey, M.; Ahmad, N.; Rajab, N.F. Bacterial cellulose/acrylic acid hydrogel synthesized via electron beam irradiation: Accelerated burn wound healing in an animal model. Carbohydr. Polym. 2014, 114, 312-320. [CrossRef]

74. Yasasvini, S.; Anusa, R.S.; VedhaHari, B.N.; Prabhu, P.C.; RamyaDevi, D. Topical hydrogel matrix loaded with Simvastatin microparticles for enhanced wound healing activity. Mater. Sci. Eng. C Mater. Biol. Appl. 2017, 72, 160-167. [CrossRef] [PubMed]

75. Bhattarai, N.; Gunn, J.; Zhang, M. Chitosan-based hydrogels for controlled, localized drug delivery. Adv. Drug Deliv. Rev. 2010, 62, 83-99. [CrossRef]

76. Dorrani, M.; Kaul, M.; Parhi, A.; LaVoie, E.J.; Pilch, D.S.; Michniak-Kohn, B. TXA497 as a topical antibacterial agent: Comparative antistaphylococcal, skin deposition, and skin permeation studies with mupirocin. Int. J. Pharm. 2014, 476, 199-204. [CrossRef]

77. Kennedy, P.; Brammah, S.; Wills, E. Burns, biofilm and a new appraisal of burn wound sepsis. Burns 2010, 36, 49-56. [CrossRef]

78. Nisini, R.; Poerio, N.; Mariotti, S.; De Santis, F.; Fraziano, M. The Multirole of Liposomes in Therapy and Prevention of Infectious Diseases. Front. Immunol. 2018, 9, 155. [CrossRef]

79. Wang, D.Y.; van der Mei, H.C.; Ren, Y.; Busscher, H.J.; Shi, L. Lipid-Based Antimicrobial Delivery-Systems for the Treatment of Bacterial Infections. Front. Chem. 2019, 7, 872. [CrossRef] 
80. Grijalvo, S.; Mayr, J.; Eritja, R.; Díaz, D.D. Biodegradable liposome-encapsulated hydrogels for biomedical applications: A marriage of convenience. Biomater. Sci. 2016, 4, 555-574. [CrossRef]

81. Campos, E.; Branquinho, J.; Carreira, A.S.; Carvalho, A.; Coimbra, P.; Ferreira, P.; Gil, M.H. Designing polymeric microparticles for biomedical and industrial applications. Eur. Polym. J. 2013, 49, 2005-2021. [CrossRef]

82. Singhvi, G.; Manchanda, P.; Hans, N.; Dubey, S.K.; Gupta, G. Microsponge: An emerging drug delivery strategy. Drug Dev. Res. 2019, 80, 200-208. [CrossRef] [PubMed]

83. de la Puente, P.; Ludeña, D.; Fernández, A.; Aranda, J.L.; Varela, G.; Iglesias, J. Autologous fibrin scaffolds cultured dermal fibroblasts and enriched with encapsulated bFGF for tissue engineering. J. Biomed. Mater. Res. Part A 2011, 99A, 648-654. [CrossRef] [PubMed]

84. Kumar, P.; Burman, U.; Kaul, R.K. Chapter 19 - Ecological Risks of Nanoparticles: Effect on Soil Microorganisms. In Nanomaterials in Plants, Algae, and Microorganisms; Tripathi, D.K., Ahmad, P., Sharma, S., Chauhan, D.K., Dubey, N.K., Eds.; Academic Press: Cambridge, MA, USA, 2018; pp. 429-452.

85. Mihai, M.M.; Dima, M.B.; Dima, B.; Holban, A.M. Nanomaterials for Wound Healing and Infection Control. Materials 2019, 12, 2176. [CrossRef]

86. Gupta, S.; Bansal, R.; Gupta, S.; Jindal, N.; Jindal, A. Nanocarriers and nanoparticles for skin care and dermatological treatments. Indian Dermatol. Online J. 2013, 4, 267-272. [CrossRef] [PubMed]

87. Norouzi, M.; Boroujeni, S.M.; Omidvarkordshouli, N.; Soleimani, M. Advances in skin regeneration: Application of electrospun scaffolds. Adv. Healthc. Mater. 2015, 4, 1114-1133. [CrossRef]

88. Homaeigohar, S.; Boccaccini, A.R. Antibacterial biohybrid nanofibers for wound dressings. Acta Biomater. 2020, 107, 25-49. [CrossRef] [PubMed]

89. Iacob, A.-T.; Drăgan, M.; Ionescu, O.-M.; Profire, L.; Ficai, A.; Andronescu, E.; Confederat, L.G.; Lupașcu, D. An Overview of Biopolymeric Electrospun Nanofibers Based on Polysaccharides for Wound Healing Management. Pharmaceutics 2020, $12,983$. [CrossRef] [PubMed]

90. Abrigo, M.; McArthur, S.L.; Kingshott, P. Electrospun nanofibers as dressings for chronic wound care: Advances, challenges, and future prospects. Macromol. Biosci. 2014, 14, 772-792. [CrossRef] [PubMed]

91. Chinsriwongkul, A.; Chareanputtakhun, P.; Ngawhirunpat, T.; Rojanarata, T.; Sila-on, W.; Ruktanonchai, U.; Opanasopit, P. Nanostructured Lipid Carriers (NLC) for Parenteral Delivery of an Anticancer Drug. AAPS PharmSciTech 2012, 13, 150-158. [CrossRef]

92. Chatterjee, S.; Sen, S.; Hazra, A.; Das, A.K. Randomized controlled trial of topical mupirocin versus mupirocin with sucralfate combination in chronic skin ulcers. Indian J. Pharmacol. 2019, 51, 316-322. [CrossRef]

93. Kifer, D.; Mužinić, V.; Klarić, M. Antimicrobial potency of single and combined mupirocin and monoterpenes, thymol, menthol and 1,8-cineole against Staphylococcus aureus planktonic and biofilm growth. J. Antibiot. 2016, 69, 689-696. [CrossRef]

94. Jagdale, S.C.; Kothekar, P.V. Development of Emulgel Delivery of Mupirocin for Treatment of Skin Infection. Recent Pat. Antiinfect. Drug Discov. 2020, 15, 137-156. [CrossRef] 